\title{
ENIGMAS IN ASSESSING THE COMPOSITION OF A ROCK UNIT: \\ A CASE HISTORY BASED ON THE MALSBURG GRANITE, SW. GERMANY*
}

\author{
E. H. Tімотнy Whitten
}

\begin{abstract}
Whitten, E. H. T. 1972: Enigmas in assessing the composition of a rock unit: a case history based on the Malsburg Granite, SW. Germany. Bull. Geol. Soc. Finland 44, 47-82.
\end{abstract}

In a continuing attempt to evaluate how the three-dimensional composition and variability of rock units can be assessed correctly, this paper focuses on critical sampling problems involved. The compositional variability and zonation of the Malsburg Granite has already received considerable attention on the basis of large numbers of modes (Rein, 1961), alkali analyses (Mehnert and Willgallis, 1961), and analyses of 8 elements (Hahn-Weinheimer and Ackermann, 1967). New analyses for 10 major oxides are presented for 37 localities used by the previous workers. The unique assemblage of independent sets of analyses permits evaluation of both the sampling problems and the different methods of assessing the three-dimensional variability of the granite mass. The available data do not readily permit statistical discrimination of the petrographically- and petrogenetically-significant zones that have previously been appropriately (but subjectively) delineated by the integration of numerous attributes that cannot be measured with existing techniques. The urgent need to identify and measure those variables critical to evaluating particular descriptive and genetic granite problems is emphasized. It is concluded that, on the basis of the available modal and chemical data, Q-mode factor analysis maps provide the best available method of remapping the zones previously identified in the Malsburg Granite; this results, in part, from the simultaneous use of numerous variables.

E. H. Timotby Whitten, Department of Geological Sciences, Nortbwestern University, Evanston, Illinois 60201, U.S.A.

* Presented orally at Pŕíbram, Czechoslovakia, in October, 1970, as an invited paper, Section of Mathematical Methods in the Earth Sciences of the 'Mining Príbram in Science and Technics, 1970' and used as the basis of two lectures in the Department of Geology and Mineralogy, Unirersity of Helsinki in April, 1971. 


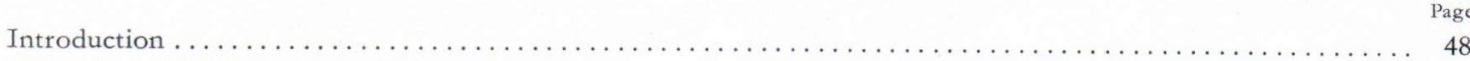

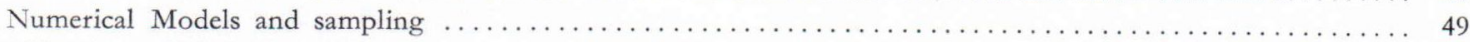

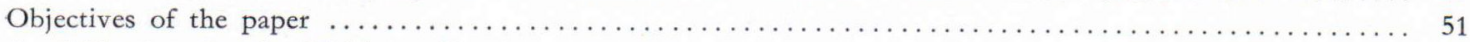

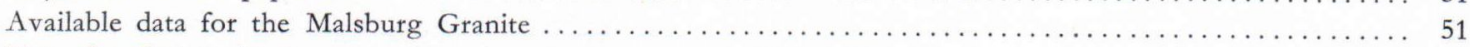

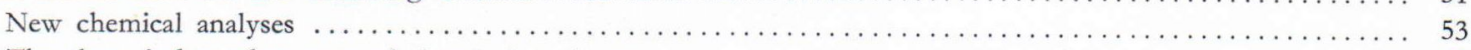

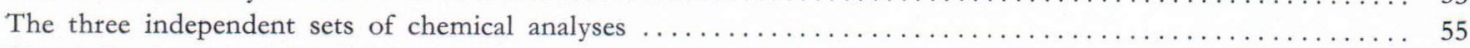

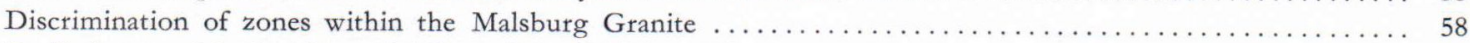

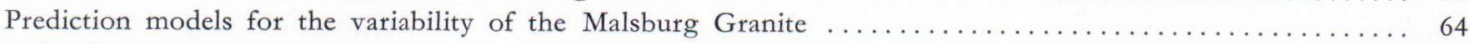

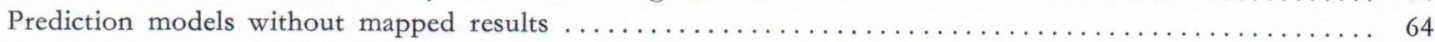

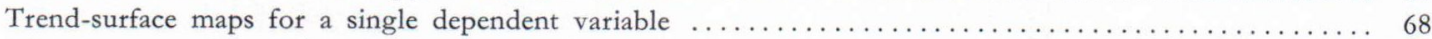

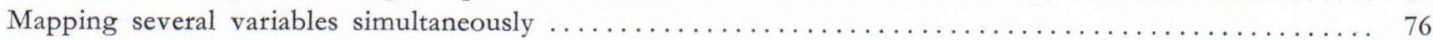

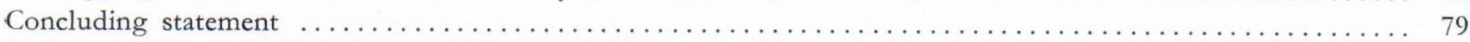

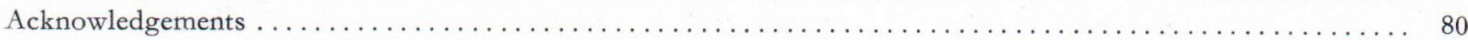

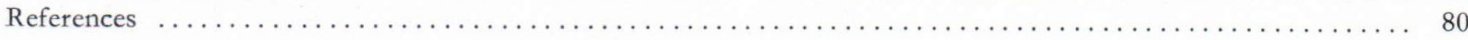

\section{Introduction}

Controversy about the genesis of granitoid rocks has continued for many decades without the emergence of laws that would permit a field geologist to identify unequivocally the correct petrogenetic model for a particular complex. Commonly, $n$ different magmatic and/or replacement petrogenetic models can be visualized for a specific granitoid mass. In fact, however, although many identifiable discrete petrogenetic steps may have been involved, there is only one correct genetic model for each specific mass. It is legitimate to enquire which (if any) actual characteristics of a granitoid mass permit adequate discrimination between the true and the various false genetic hypotheses.

In the geological study of a new area of varied rocks, considerable time may be spent collecting miscellaneous information about numerous different variables. By manipulation of the assembled data some interesting results may emerge that could be considered the 'objective'. However, if the objective of the research is defined carefully at the beginning of the study, data for variables of specific significance to that problem could be collected. Most studies of granitic complexes are embellished with a few chemical and/or modal analyses of selected samples - variables that have traditionally been measured and recorded in a quantitative manner. If the study objective is purely descriptive, it would be reasonable to enquire whether a published set of analyses permits the reader to develop an accurate three-dimensional picture that is adequate to assess the degree of similarity with other rock units. On visiting a granitic complex described in the literature, it is a common experience to find it different from the mental picture developed from the description; in such cases, seeing the rocks in the field is vital to obtaining a 'complete' impression.

A mineralogist can describe properties of a crystal in such a way that a scientist on another continent can be sure (within reasonable confidence limits) whether his material is the same or not. Petrologists are in a far less enviable position. If geology is a branch of physical science, petrologists must become able to communicate descriptive results in an unequivocal manner so that published results and observations can be reproducible (as can results and experiments of chemists and physicists.) The task is great because rock units are such complex systems. However, the alternative leads to chaos.

Experimental silicate geochemistry has led to many significant advances in granite petrology. However, in the course of field and laboratory 
studies of granitoid complexes, the most highly respected petrologists integrate mentally many properties that are rarely expressed objectively; interpretation of a new mass is based on their integrated experience. Clearly, many more features are appraised by the experienced petrologist than are recorded in a published description. To acquire similar competence, an aspiring geologist needs to see the same sequence of exposures and to emphasize mentally the same subjectivelyevaluated features. Such wide experience is not available to all and the experience cannot be tested objectively or scientifically - it is an outdated approach inappropriate to a physical science. In fact, each feature of an outcrop or a thin section can be described in terms of operational definitions that would ensure that any scientist could replicate measurements. Increased technological competence now permits the compositional variability of chemical elements to be measured very accurately (and to be considered a necessary component of many petrological and petrographic papers). It is incredible, however, that there are still no standard, precise, operational definitions for the more obvious petrographically-important properties of igneous rocks (e.g., texture, grain size, jointing, xenolith content), and that such properties remain unmapped and very difficult to describe for scientific communication. The three-dimensional variability of hundreds of chemical, modal, mineralogical, optical, textural, and structural features of a granitoid mass could be objectively described. It is clearly unrealistic to determine the spatial variability of them all. If the objective of the study is petrogenetic, only those variables that permit discrimination between the several petrogenetic models may be worthy of study. Unfortunately, the variables most significant for such discrimination are, in general, unknown. It is likely that the variables classically recorded in papers (e.g., quartz volume per cent., $\mathrm{CaO}$ weight per cent., normative albite) may be extremely inefficient discriminants ( $c f$., Chayes and Velde, 1965).
If the three-dimensional distribution of the significant mineralogical, chemical, and textural components were known, it should be realistic to develop conceptual petrogenetic models for lithic units. When attempting to define the best mathematical model for a particular earthscience problem, it is becoming standard practice to approximate the available quantitative and qualitative data with the best current model and then to examine critically both the fit and the anomalous departures of the observed data from the model estimates. In deterministic situations, the anomalies are likely to be minor. In geological contexts, however, the deviations commonly account for large and significant proportions of the total observed variability. If the data are wholly adequate and appropriate to the problem, but the model is inadequate, successive modifications should achieve progressively more efficient models; at each iteration, critical reappraisal of anomalous samples can be expected to give considerable insight into the nature and significance of minor geological features that are largely masked by the regional patterns of variability.

\section{Numerical models and sampling}

The general availability of computers has permitted numerous quantitative and mathematical techniques to be applied to many aspects of economic geology and to the petrologic and petrographic study of individual rock complexes. This is a significant advance for geology if, as has been suggested (Griffiths, 1962, p. 565), »Progress in scientific investigation in any specialized field is generally measured by the degree to which the subject is pervaded by mathematics.» However, the value of this technology depends upon the quality and significance of the data used for the mathematical analyses.

Unfortunately, this widespread availability of computer-based techniques for manipulating and analyzing data has tended to distract attention from the nature and meaning of the original 
data. Commonly, insufficient attention has been given to the appropriateness of both the variables and the sampled population (for which the data are available), in relation to the target population of interest. When an array of numerical values has been obtained, it is not unusual to associate with it a subjective feeling of accuracy and correctness (especially after it has been processed and transformed into a new tabular or map format), that may be wholly unwarranted. Frequently, it is difficult or impossible to evaluate the geological significance of available data, although the geologist is commonly tempted to extrapolate and/or interpolate on the basis of available numerical values. In doing this, statistical techniques are frequently used after collection of data in an essentially arbitrary manner; at best, this tends to be inefficient and, at worst, it is completely ineffective ( $c f$., Griffiths, 1962, p. 567).

Analytical data are developed for specimens collected from a sampled population but, in almost all geological situations, such observations do not permit statistical inferences to be made about the target population (Whitten, 1961). The numerous current statistical techniques can be used to analyze a data set fully and confidence levels can be associated with statements about the data. It may also be possible to make meaningful geological statements about the target population of interest on the basis of the sampled-population data, but such statements must rely on geological interpretation, rather than on statistical inference. Despite this inherent limitation, it has become common practice in routine petrographic studies to erect petrogenetic and/or economic hypotheses on the basis of a limited set of objective data augmented by subjectively-appraised attributes. The raw quantitative data for granitic complexes, for example, are relatively difficult and/or expensive to obtain. Despite the availability of the so-called rapid methods of chemical analysis and the demonstration that abundant, very accurate, and precise data can be obtained (e.g., Baird, et al., 1967,
Chappell, 1966, Rhodes, 1970), for economic reasons many geologists are still obliged to rely on a limited number of analytical results.

In a few petrographic studies, very detailed sampling and analytical programs have permitted realistic models to be erected for the specified target population. In most cases, however, very limited information is available about the levels of variance of each of the several hundred variables that could be measured. Because different variables in a particular lithic unit tend to have dissimilar levels of variance, different sampling plans are, in general, needed to establish (to the same degree of confidence) the variability pattern of each variable. Hence, it becomes very difficult, if not impossible, to determine whether the apparent pattern (established on the basis of available data for a lithic unit) and any local anomalies reflect errors or sampling and/or analytical inadequacies. Apparent anomalies could indicate an inadequate model requiring modification, or that the analytical data for the sampled population are an inadequate source of information about the target population of interest.

An example is appropriate. In constructing a trend-surface map for, say, modal quartz percentage in 50 granite samples, the sum of squares reduction (possibly tested with a $F$ test) and a confidence band may indicate a very 'good' surface for describing the data set. Despite the apparently-excellent statistical tests, the surface could be a wholly misleading descriptor of the target population; such a situation could arise if each mode were based on a single, small thin section of samples collected from a granite mass seen to be heterogenous in outcrop, where the geologist has defined the target population as all of the $3 \mathrm{~m}^{2}$ unit areas that comprise the mapped surface area of the granite. Statistical manipulation cannot transform inappropriate data into a true image of the target population. Where the same samples have been used for measuring different variables, the significance of the values for each variable will, in general, be 
dissimilar because in samples of a given size the variance of each variable tends to be different. Commonly, inadequate data are difficult to evaluate and acknowledge.

\section{Objectives of the paper}

In most geological studies replicate sets of both samples and analytical data are not available. However, continuing study of the Malsburg Granite in the southern Black Forest, SW. Germany, has provided several sets of independently-derived data. Each set could, in common usage, be the basis of petrographic and petrogenetic models. Without in any way implying criticism of the results already published, it is intended to draw attention to the dissimilarity of these "apparently-adequate» sets of data and to the inherent difficulty of using any one of them as a basis for testing or confirming the excellent petrogenetic models developed and refined by very competent petrologists (who have integrated extensive subjective and objective field and laboratory experience.) Such a discussion of the sampling and/or analytical problems inherent in all, or some, of the sets of analyses could be discouraging. However, more positive conclusions should be drawn. It is the purpose of this paper to emphasize the extreme importance of two fundamental factors in petrology that have been almost wholly ignored. First, that extreme caution must be used in basing conclusions on numerical data for which full information about levels of variance for each variable are not known; the levels of variance of each studied variable are commonly unknown, but are of fundamental importance for devizing a statistically-appropriate sampling plan and for interpreting the significance of an available data set. Second, because petrologists place great importance on many textural and structural characters, it is imperative that such features be objectively described in terms of precise operational definitions; this will permit these important fea- tures to be incorporated within statisticallyadequate sampling procedures that are a prerequisite to scientific study of rock units. In this paper, it is intended to draw attention to some of the problems that arise when these types of information are not available. It is hoped that this will serve as a challenge to petrographers where it is desired to obtain the answer, rather than an answer.

Finally, it is suggested that, where complete variance information is not available and a completely satisfactory sampling scheme is not available, maps based on multivariate Q-mode factor analysis can portray the spatial variability of a granite mass more realistically than maps showing the regional and local variability of individual variables. Although having a general resemblance to the published models for the Malsburg Granite, the Q-mode maps show significant differences that must have importance in any petrogenetic study of the complex.

\section{Available data for the Malsburg Granite}

The petrography and petrogenesis of the Malsburg Granite have received considerable attention in the past (e.g., Schröder, 1929; Mehnert and Willgallis, 1957; Zimmerle, 1958; Mehnert, 1963; Barthel and Mehnert, 1970; Willgallis, 1970). Mehnert (1960) and Mehnert and Willgallis (1961) published $\mathrm{K}_{2} \mathrm{O}$ and $\mathrm{Na}_{2} \mathrm{O}$ weight percentage values and geographical grid locations for 120 samples of the granite and Whitten (1962; 1963) used polynomial trend-surface analysis to evaluate the three-dimensional spatial variability of these valuable data. Leible (1959) had earlier published thorium and uranium analyses for 16 localities and thorium plus uranium radiation values for these and for 47 additional sites. An excellent series of detailed modal variation maps based on micrometric analyses was given by Rein (1955, 1961); most of his specimens were collected from the same localities as those used by Mehnert and Willgallis (1961).

Hahn-Weinheimer and Ackermann 


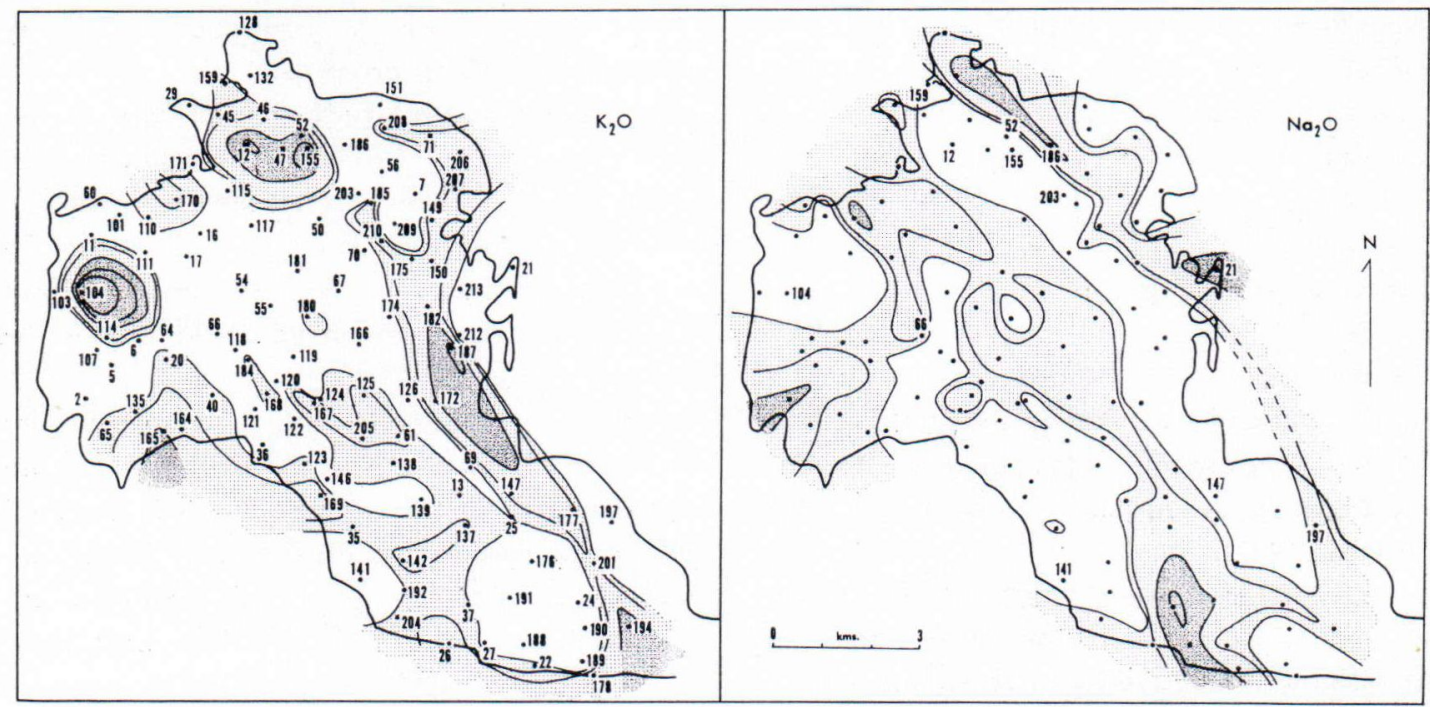

Fig. 1. Manual contours for positive deviations from the degree 3 polynomial trend surfaces computed for $110 \mathrm{~K}_{2} \mathrm{O}$ and $\mathrm{Na}_{2} \mathrm{O}$ weight percentage analyses of Malsburg Granite samples published by Mehnert and Willgallis (1961); the sample numbers are those used by Rein (1961), Mehnert and Willgallis (1961), and throughout this paper. Contours at $0,0.1,0.3$, and 0.5 per cent.

used X-ray fluorescence analyses to estimate the local heterogeneity of $\mathrm{K}$ and $\mathrm{Ti}$ weight percentages, and of $\mathrm{Zr}, \mathrm{P}, \mathrm{Sr}, \mathrm{Ba}$, and $\mathrm{Rb}$ p.p.m. in the Malsburg Granite. On the basis of samples from 90 of Mehnert and Willgallis' (1961) and Rein's (1961) localities, Hahn-Weinheimer and Ackermann (1967) prepared maps of equal concentration of these same elements and for $\mathrm{Na}$ weight percentage (determined by neutron activation analysis).

A polynomial regression model (Whitten, 1962) for $\mathrm{K}_{2} \mathrm{O}$ and $\mathrm{Na}_{2} \mathrm{O}$ revealed marked autocorrelation of the deviations (Fig. 1). The linear bands of positive and negative deviations raised the question of whether distinct local geological features occur in the granite and account for the departures of the observed alkali values from the computed model; the patterns are reminiscent of the palimpsestic ghost stratigraphy described in the "older granite» of Donegal (Whitten, 1960). However, when the maps for the Malsburg Granite were published, no attempt had been made to re-examine the anomalous sample localities in the field. The present research was origi- nally aimed at determining the significance of these deviation patterns. In 1962, the present author collected specimens from many of the localities defined by Mehnert and Willgallis (1961) and Rein (1961); emphasis was placed on localities that define the deviations shown in Figure 1. The ten major oxides and specific gravity were determined for samples from 37 of these localities; the analyses (Table 1) have not been published previously.

Available analytical data for the Malsburg Granite is unique. Because the granite outcrops in an area of considerable relief, significant advantages stem from considering the threedimensional, in addition to the geographical, variability. Modal analyses (Rein), three independent sets of partial chemical analyses(Mehnert and Willgallis, Hahn-Weinheimer and Ackermann, and Whitten), and norms and specific gravity values (Whitten) are all available for the same 37 grid locations. These data permit interesting comparisons to be made. As with data in most published petrographic studies, there is little alternative to giving equal statistical signi- 
ficance and authenticity to each analytical value, unless the actual sample sites can be visited by the reader. The Malsburg Granite sample sites are probably not unique in having distinct dissimilarities (as described in a later section).

\section{New chemical analyses}

The Malsburg Granite is poorly exposed; much of the outcrop area is open pastoral or arable land and part is forested. The geographic coordinates published by Mehnert and Willgallis (1961, Table 16) and Rein (1961, Table 11) make it relatively easy to locate almost all of their outcrops; through the courtesy of Drs. Rein and Ackermann, 1: 25000 topographical maps showing the actual sample localities were also available.

The field work and sampling in 1962 were primarily directed towards establishing the significance of the deviations (Fig. 1) from the polynomial trend surfaces computed (Whitten, 1962) for Mehnert and Willgallis' (1961) $\mathrm{K}_{2} \mathrm{O}$ and $\mathrm{Na}_{2} \mathrm{O}$ data. That is, specific search was made in the field for any features that could partially explain the autocorrelations reflected by the deviation maps (Fig. 1). In view of the traditional problems associated with quantitative analyses of $\mathrm{K}_{2} \mathrm{O}$ and $\mathrm{Na}_{2} \mathrm{O}$, significant deviations might be anticipated to arise from analytical errors. High variance at the outcrop or sample-size level or even clerical errors might explain some of the anomalies. However, in 1962, the strong autocorrelation of deviations was thought to favor an underlying, geological control of the local anomalies.

At many outcrops the granite is very deeply weathered. Care was taken to extract the freshest available material with crow-bar and hammer. Samples were not collected from any locality without carefully determining whether the granite was in situ. At several of the localities associated with very large deviations in Figure 1 , it proved impossible to find any outcrop and/or in situ material.
Selected samples were powdered at Northwestern University and the new chemical analyses were completed in 1965 by Japan Analytical Chemistry Research Institute (Executive Director: Dr Tamiya Asari). $\mathrm{SiO}_{2}, \mathrm{Al}_{2} \mathrm{O}_{3}, \mathrm{CaO}$, $\mathrm{MgO}$, and $\mathrm{P}_{2} \mathrm{O}_{5}$ were determined by gravimetric, $\mathrm{Fe}_{2} \mathrm{O}_{3}$ and $\mathrm{FeO}$ by volumetric, $\mathrm{TiO}_{2}$ by photometric, and $\mathrm{Na}_{2} \mathrm{O}$ and $\mathrm{K}_{2} \mathrm{O}$ by flame-photometric methods. Hidden duplicates of six of the 37 samples were also analyzed at the same time. As an added check on reproducibility, $\mathrm{FeO}$ was reanalyzed for 10 samples (and ignition loss determined for these samples), 8 samples were reanalyzed for $\mathrm{CaO}$, and 11 for both $\mathrm{Na}_{2} \mathrm{O}$ and $\mathrm{K}_{2} \mathrm{O}$. The complete analytical results are shown in Table 1; four different analysts from Dr. Asari's laboratory were responsible for this work. Dr. Asari (personal communication) assumed that few analytical errors should be involved with $\mathrm{SiO}_{2}, \mathrm{MgO}, \mathrm{CaO}, \mathrm{Na}_{2} \mathrm{O}, \mathrm{K}_{2} \mathrm{O}$ and $\mathrm{TiO}_{2}$, although he suggested that errors might be anticipated with $\mathrm{Al}_{2} \mathrm{O}_{3}, \mathrm{Fe}_{2} \mathrm{O}_{3}-\mathrm{FeO}$, and $\mathrm{P}_{2} \mathrm{O}_{5}$ (which are calculated by differences). Additional evidence for the confidence levels to be associated with these chemical analyses is not available. There is no reason to suppose that these analyses are superior to others published for the Malsburg Granite; they simply represent the type of analyses commonly available and used in petrological papers.

Ignition loss reported for these analyses ranges up to about 4 per cent. It is not recorded whether the partial analyses published previously (Mehnert and Willgallis, 1961, and Hahn-Weinheimer and Ackermann, 1967) have been adjusted for ignition losses. Figure 2 shows the original $\mathrm{K}_{2} \mathrm{O}$ weight percentages from Table 1 contrasted with the values recalculated to eliminate ignition loss. Figure 3 shows that maps for these two sets of values are not materially different (except that the repercentaged values are approximately 0.1 per cent larger). The ignition-loss problem is eliminated by the use of oxide ratios, although ratios of closed-system data (percentages) introduce additional statistical problems. The geo- 


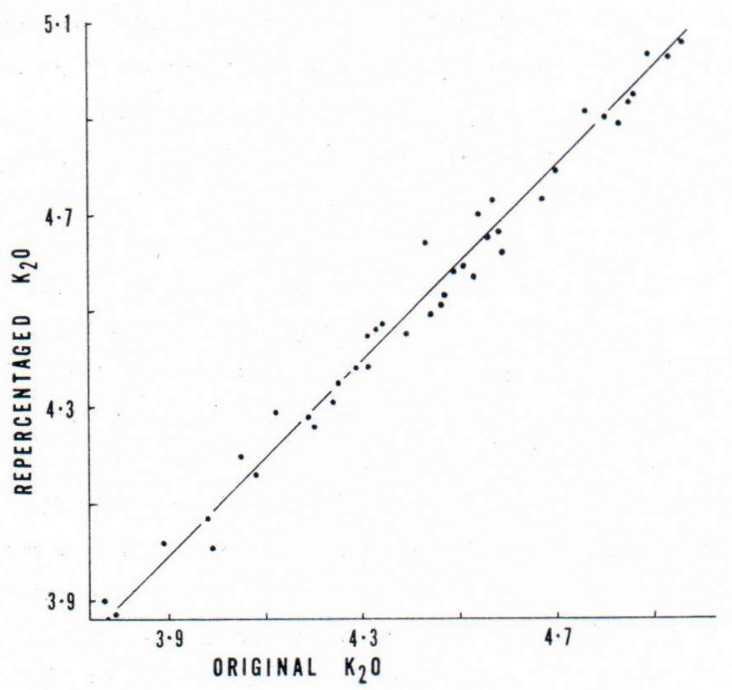

Fig. 2. Whitten $\mathrm{K}_{2} \mathrm{O}$ weight percentages (from Table 1) and $\mathrm{K}_{2} \mathrm{O}$ values recalculated to eliminate ignition loss; where ignition loss was not determined, it was assumed that the loss would account for the difference between the analysis total and 100 per cent.

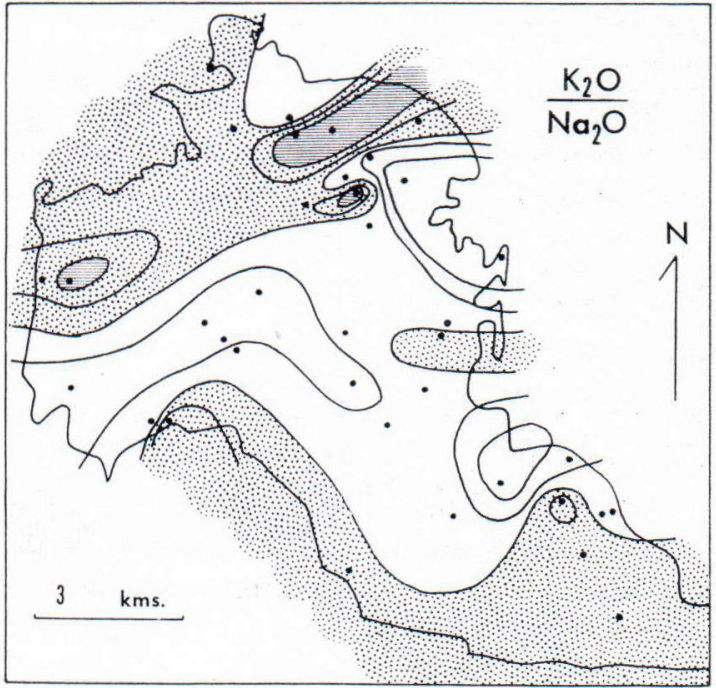

Fig. 4. Manually-contoured map of the Malsburg Granite for $\mathrm{K}_{2} \mathrm{O}: \mathrm{Na}_{2} \mathrm{O}$ ratio (derived from Table 1 for 37 samples). Contours at 1.0 and each 0.1 per cent increment; above 1.2 stippled and above 1.4 ruled.

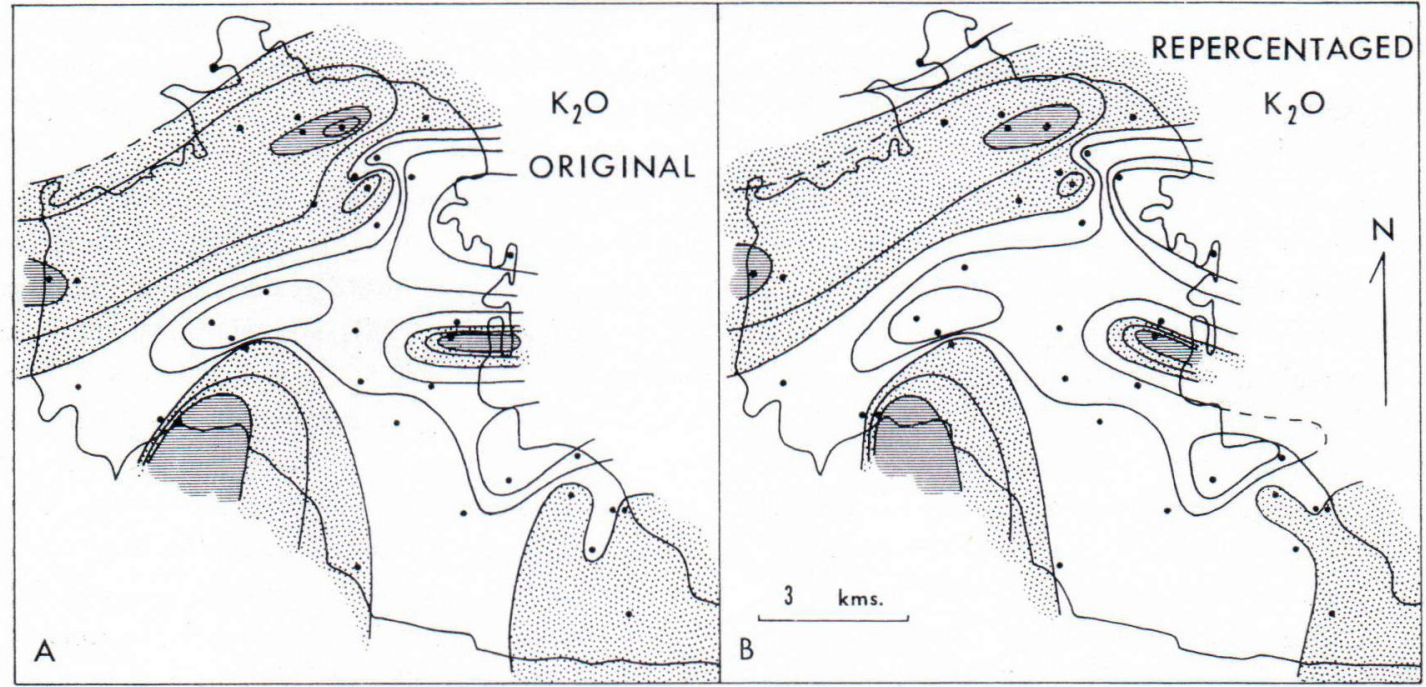

Fig. 3. Manually-contoured maps of the Malsburg Granite for the original $37 \mathrm{~K}_{2} \mathrm{O}$ percentages (from Table 1) and for $\mathrm{K}_{2} \mathrm{O}$ recalculated to eliminate ignition loss. $A$ : Contours at 3.9 and each 0.2 per cent increment; above 4.5 stippled and above 4.9 ruled. $B$ : Contours at 4.0 and each 0.2 per cent increment; above 4.6 stippled and above 5.0 ruled. 
logical significance of oxide ratios is not always obvious but, in this case, the $\mathrm{K}_{2} \mathrm{O} / \mathrm{Na}_{2} \mathrm{O}$ ratio (Fig. 4) has a somewhat similar map pattern to that for $\mathrm{K}_{2} \mathrm{O}$ weight percentage (Fig. 3).

\section{The three independent sets of chemical analyses}

Hahn-Weinheimer and Ackermann (1967, p. 2217) considered that, on the whole, their results for $\mathrm{Na}$ and $\mathrm{K}$ are in agreement with the flame photometric determinations of Mehnert and Willgallis (1961). However, the linear correlation coefficient for $\mathrm{K}_{2} \mathrm{O}$ and $\mathrm{K}$ of these workers is 0.73 and only 0.45 for $\mathrm{Na}_{2} \mathrm{O}$ and $\mathrm{Na}$ (on the basis of 26 common sites included in Table 1). The correlation coefficient for $\mathrm{K}_{2} \mathrm{O}$ values for the 35 samples common to Mehnert and Willgallis (1961) and Table 1 is only 0.45; for the corresponding $\mathrm{Na}_{2} \mathrm{O}$ values, the coefficient is 0.39 . The relatively small magnitude of these correlation coefficients (Table 2) suggests that the three sets of chemical analyses should be scrutinized more thoroughly. Whitten's $\mathrm{K}_{2} \mathrm{O}$ values (Table 1) and those of Mehnert and Willgallis (1961) are plotted against Hahn-Weinheimer and Ackermann's (1967) $\mathrm{K}$ values in Figures $5 \mathrm{~B}$ and $5 \mathrm{C}$; the $\mathrm{K}_{2} \mathrm{O}$ analyses of Mehnert and Willgallis (1961) and Whitten (Table 1) are compared in Figure 5 A. Figure 6 shows similar diagrams for $\mathrm{Na}_{2} \mathrm{O}$ and $\mathrm{Na}$ percentages. The $\mathrm{TiO}_{2}$ percentages from Table 1 and Hahn-Weinheimer and Ackermann's (1967)

\section{TABle 2}

Linear correlation coefficients based on the sample localities common to all three sets of chemical analyses

\begin{tabular}{|c|c|c|c|}
\hline Source of analyses & $\mathrm{K}_{2} \mathrm{O} / \mathrm{K}$ & $\mathrm{Na}_{2} \mathrm{O} / \mathrm{Na}$ & $\mathrm{TiO}_{2} / \mathrm{Ti}$ \\
\hline Mehnert and Willgallis and & \multirow{3}{*}{0.73} & \multirow{3}{*}{0.45} & \multirow{3}{*}{ —* } \\
\hline $\begin{array}{l}\text { Hahn-Weinheimer and } \\
\text { Ackermann } \ldots \ldots \ldots \ldots \ldots\end{array}$ & & & \\
\hline Mehnert and Willgallis and & & & \\
\hline Whitten $\ldots \ldots \ldots \ldots$ & 0.45 & 0.40 & —* \\
\hline Hahn-Weinheimer and & & & \\
\hline Ackermann and Whitten & 0.71 & 0.57 & 0.84 \\
\hline
\end{tabular}

* Mehnert and Willgallis did not give $\mathrm{TiO}_{2}$ analyses.
Ti values are compared in Figure 7 . Each of these graphs shows considerable scatter which may reflect

(a) analytical or clerical errors within either or both sets of analyses - either random errors, consistent bias in one or more analytical technique, or variability within the limits of precision of the analytical methods,

(b) local variability within the sample sites designated by the geographic coordinates, or

(c) sampling differences or errors in the field - assignment of incorrect coordinates or collection of specimens from the wrong locality, from erratic material, or from material too weathered or too decomposed to represent the fresh parent rock.

In preliminary tests, Hahn-Weinheimer and Ackermann $(1963,1967)$ found that their X-ray fluorescence analyses have small errors and mean deviations in comparison with the variances of groups of samples from localities 20,66, 69, and 128 (see Figure 1). The coefficients of variation* deduced by these authors are shown in Table 3 . Local heterogeneity was estimated on the basis of 9 to 13 samples of 5 to $10 \mathrm{~kg}$ each collected at 10 to $15 \mathrm{~m}$ intervals in each outcrop. Intuitively, the variances deduced for $\mathrm{Ca}$ weight percentage appear to be surprisingly large. HahnWeinheimer and Ackermann implied that the

* The coefficient of variation is the standard deviation divided by the mean and then expressed as a percentage.

TABLE 3

Coefficients of variation for experimental error and local heterogeneity in outcrops estimated by Hahn-Weinheimer and Ackermann (1963, 1967)

\begin{tabular}{l|c|r|r|r|r}
\hline Element & $\begin{array}{c}\text { Experi- } \\
\text { mental error }\end{array}$ & $\begin{array}{c}\text { Locality } \\
20(\mathrm{~N}=13)\end{array}$ & $\begin{array}{c}\text { Locality } \\
66(\mathrm{~N}=10)\end{array}$ & $\begin{array}{c}\text { Locality } \\
69(\mathrm{~N}=10)\end{array}$ & $\begin{array}{c}\text { Locality } \\
128(\mathrm{~N}=9)^{*}\end{array}$ \\
\hline $\mathrm{K} \ldots \ldots$ & 0.37 & 2.61 & 2.72 & 3.79 & 4.58 \\
$\mathrm{Na} \ldots \ldots$ & 0.70 & 3.11 & 3.09 & 2.62 & 3.27 \\
$\mathrm{Ca} \ldots \ldots$ & 0.49 & 21.35 & 14.35 & 10.60 & 17.10 \\
$\mathrm{Ti} \ldots .$. & 0.58 & 7.77 & 4.67 & 3.13 & 2.86
\end{tabular}

$* \mathrm{~N}=$ number of samples individually analyzed for that locality. 

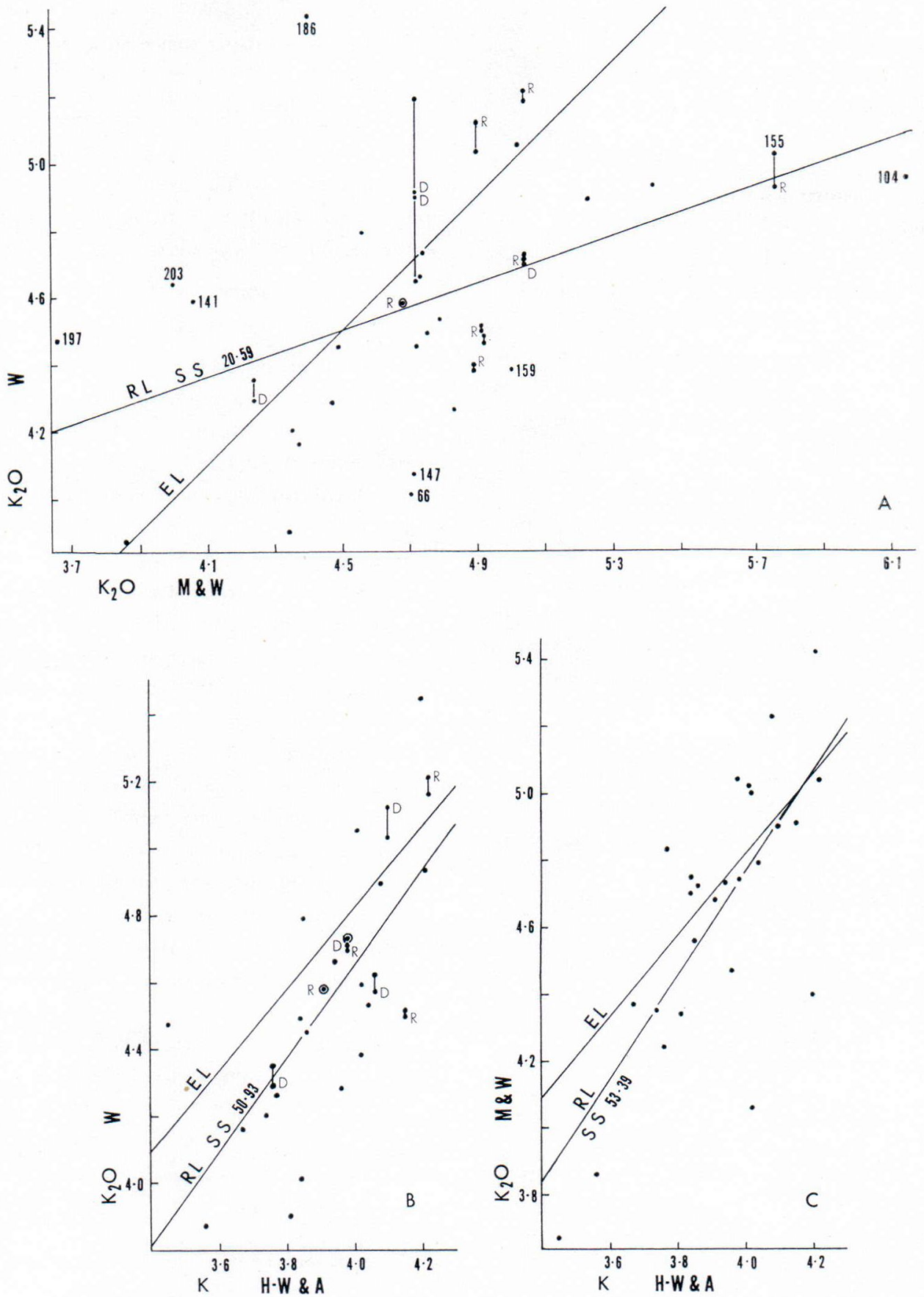

Fig. 5. Comparisons of the independent $\mathrm{K}_{2} \mathrm{O}$ and $\mathrm{K}$ analyses made by Whitten (W), Mehnert and Willgallis ( $M$ \& W), and Hahn-Weinheimer and Ackermann ( $\mathrm{H}-\mathrm{W} \& \mathrm{~A}$ ) for samples collected from the same localities of the Malsburg Granite. EL = expected line along which analyses should lie. $\mathrm{RL}=$ linear regression line for actual values (not including replicate (R) and duplicate (D) analyses shown in scatter diagrams and Table 1) with percentages of total sums of squares (SS) associated with each line. Samples falling well away from EL in Figure $5 \mathrm{~A}$ are identified by sample number. 

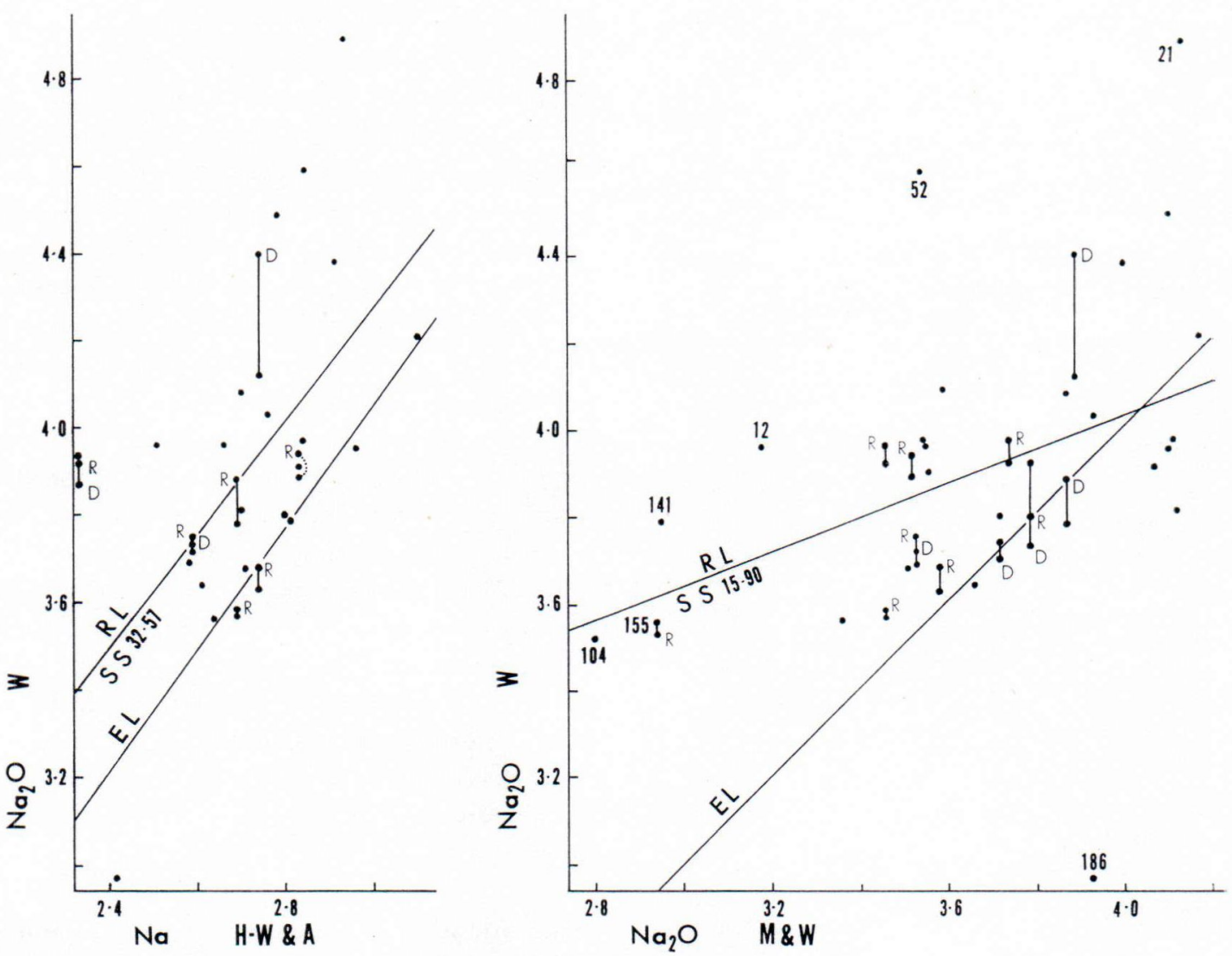

Fig. 6. Comparisons of the independent $\mathrm{Na}_{2} \mathrm{O}$ and $\mathrm{Na}$ analyses made by Whitten (W), Mehnert and Willgallis (M \& W), and Hahn-Weinheimer and Ackermann (H-W \& A) for samples from the same localities of the Malsburg Granite. $\mathrm{EL}=$ expected line along which analyses should lie. RL = regression line for actual values (not including replicate (R) and duplicate (D) analyses shown in scatter diagrams and Table 1) with percentages of total sums of squares (SS) associated with each line. Samples falling well away from EL in Figure 6 B are identified by sample number.

values in Table 3 indicate the confidence level to be associated with their complete array of Malsburg Granite analyses.

The three regression lines for Hahn-Weinheimer and Ackermann's and Whitten's values (Figs. 5 B, 6 A, and 7) show some consistent differences which suggest that constant analytical differences occur in addition to sporadic noise; these diagrams show that these samples (which were separately collected from the same grid locations) have surprisingly little local variability. By comparison, the correlations of the alkali analyses derived by Mehnert and Willgallis and by Whitten are significantly weaker (Figs. $5 \mathrm{~A}$ and 6 B). Seven specimens (localities 12, 21, 52, $104,141,155$, and 186) on the $\mathrm{Na}_{2} \mathrm{O}$ weight percentage diagram (Fig. $6 \mathrm{~B}$ ) lie well off the theoretical expected line (EL on Fig. 6 B). Field relationships suggest that localities $12,21,52$, and 186 should not present collecting difficulties. Localities 141 and 155 are poor, weathered outcrops from which fresh rock can only be obtained after considerable labor; the geographic coordinates for 104 define the middle of an exposureless meadow which makes the origin of the previously-analyzed sample uncertain. The 




Fig. 7. Independent $\mathrm{TiO}_{2}$ analyses by Whitten (W) and 'Ti analyses by Hahn-Weinheimer and Ackermann (H-W \& A) for samples collected from the same localities of the Malsburg Granite. EL = expected line along which analyses should lie. RL = regression line for actual values (excluding replicate (R) and duplicate (D) analyses shown in scatter diagram and Table 1) with percentage of total sum of squares (SS) associated with the line.

$\mathrm{K}_{2} \mathrm{O}$ graph is less satisfactory in that nine samples lie well away from the expected line (EL on Fig. $5 \mathrm{~A}$ ), but several of these outcrops could have caused collection difficulties, viz: localities 66, 159, 186, and 197 should not have presented difficulty, except that rock at 66 and 159 is visibly heterogeneous; localities 141, 155, and 203 have poor, weathered outcrops (141 and 155 referred to previously); 147 is a poor locality essentially comprising boulders and it is uncertain whether any material is genuinely in situ; 104 was referred to above (published coordinates define exposureless meadow).

Such considerations suggest that large variances of the measured variables at the outcrop level may account for some of the scattered distribution of points in Figures $5 \mathrm{~A}$ and $6 \mathrm{~B}$. However, from these graphs it is not possible to identify the actual sources of trouble as being positively due to variance, sampling, analytical, clerical, or other error in either set of results.

Figures $5 \mathrm{~A}$ and $6 \mathrm{~B}$ have considerable importance in interpreting the deviation maps for $\mathrm{K}_{2} \mathrm{O}$ and $\mathrm{Na}_{2} \mathrm{O}$ percentages (Fig. 1). The more anomalous localities in terms of Figures $5 \mathrm{~A}$ and $6 \mathrm{~B}$ are shown in Figure 1 and they define most of the very large deviation maxima. In other words, most of the major maxima in Figure 1 occur at localities for which the data produced by different workers are not consistent.

\section{Discrimination of zones within the Malsburg Granite}

Rein (1961) showed that, for his sampled population of the Malsburg Granite, regional modal variability is much greater than the local modal variability - a conclusion subsequently supported by Hahn-Weinheimer and Ackermann (1963) on the basis of their chemical analyses of seven elements for four localities. Rein (1961) demonstrated a distinct zonal pattern for modal quartz, potash feldspar, plagioclase, biotite, hornblende, apatite, and zircon with the periphery of the granite being relatively more basic and the center more leucocratic. On the basis of their own extensive field experience and the subjectively-contoured mineralogical maps and petrographic descriptions of Rein (1961), Mehnert and Willgallis (1961, Plates 21 and 22) constructed a single qualitative petrographical map; they considered their mapped lines (incorporated 


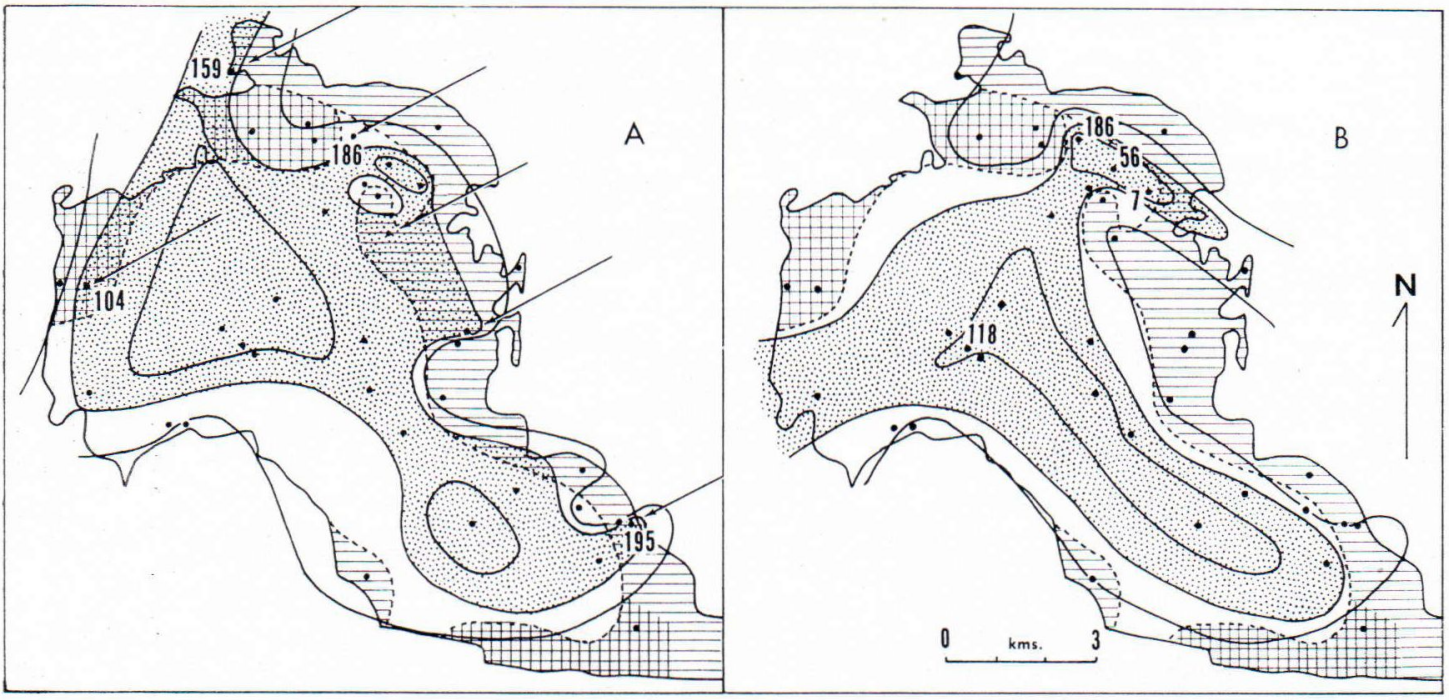

Fig. 8. Maps of discriminant functions (for 37 samples) superimposed on Mehnert and Willgallis' (1961) zones for the Malsburg Granite. No pattern - Class A central granite: Horizontal ruling - Class B border granite with partial K-feldspar porphyroblast development: Horizontal and vertical ruling - Class B $\mathrm{K}$-feldspar-blastic border granite.

A. Discriminant function for subset 2 (of Table 6): manual contours for the discriminant function are (i) within stippled area - mean value of function for specimens allocated to Class A, (ii) boundary of stippled area is the discriminant value, and (iii) outside the stippled area mean value of function for specimens allocated to Class B. The six samples misclassified by this function are indicated by arrows. The four samples most commonly misclassified (see text) are identified by sample number. $B$. Discriminant function for subset 8 (of Table 6); manual contours have same significance as in Fig. $8 \mathrm{~A}$. All samples are correctly classified. Four samples identified as transitional in character by Mehnert (see text) are identified by sample number. in Figure 8) to be somewhat arbitrary. Mehnert and Willgallis placed much importance on potash feldspar porphyroblasts and other megascopic and microscopic petrographic relationships in defining their boundaries, although quantitative information about these characteristics has not been published; in some places, the lines were shown as "uncertain.»* On these bases, Mehnert (personal communication) recognized the following zones:

\section{Inner central granite}

\section{i. Typical}

ii Transitional to the outer central granite

* Hahn-Weinheimer and Ackermann (1967) used precise mathematical operational definitions to delimit zones of equal concentration for each individual element but they did not develop a system for mapping the variability of all eight of their variables simultaneously.

\section{Outer central granite}

\section{i Typical}

ii Transitional to the inner central granite iii Transitional to the border granite

3. Border granite with partial $K$-feldspar porphyroblast development

i Typical

ii Transitional to the $\mathrm{K}$-feldspar-blastic granite

\section{K-feldspar-blastic border granite}

\section{i Typical}

ii Transitional to the outer central granite

Without questioning or debating the propriety of these zones which are probably very wellfounded petrographically, it is instructive to 
TABLE 4

Sets of data used to calculate discriminant functions and efficiences achieved

\begin{tabular}{|c|c|c|c|c|c|c|c|c|c|c|c|}
\hline \multirow{3}{*}{$\begin{array}{c}\text { Number of } \\
\text { variables }\end{array}$} & \multicolumn{8}{|c|}{ Variables used } & \multicolumn{2}{|c|}{ Number of samples } & \multirow{3}{*}{$\begin{array}{l}\text { Efficiency } \\
\text { per cent }\end{array}$} \\
\hline & \multirow[b]{2}{*}{ Elevation } & \multirow[b]{2}{*}{$\begin{array}{l}\text { Specific } \\
\text { gravity }\end{array}$} & \multicolumn{3}{|c|}{ Whitten oxides } & \multirow[b]{2}{*}{$\begin{array}{l}\text { Whitten } \\
\text { norms ex- } \\
\text { cluding Mgt }\end{array}$} & \multirow[b]{2}{*}{ Rein modes } & \multirow[b]{2}{*}{$\begin{array}{c}\text { Mehnert } \\
\mathrm{Na}_{2} \mathrm{O} \\
\mathrm{K}_{2} \mathrm{O}\end{array}$} & \multirow[b]{2}{*}{$\begin{array}{l}\text { Misclassi- } \\
\text { fied }\end{array}$} & \multirow[b]{2}{*}{ Used } & \\
\hline & & & $\left|\begin{array}{c}\mathrm{SiO}, \mathrm{Al}_{2} \mathrm{O}_{3} \\
\mathrm{CaO}, \mathrm{TiO}_{2} \\
\mathrm{P}_{2} \mathrm{O}_{5}\end{array}\right|$ & $\begin{array}{c}\mathrm{Fe}_{2} \mathrm{O}_{3} \\
\mathrm{FeO} \\
\mathrm{MgO}\end{array}$ & $\begin{array}{l}\mathrm{Na}_{2} \mathrm{O} \\
\mathrm{K}_{2} \mathrm{O}\end{array}$ & & & & & & \\
\hline 12 & \multirow[t]{3}{*}{$x$} & $x$ & $x$ & $x$ & $x$ & & & \multirow{8}{*}{$x$} & 7 & 37 & 81.1 \\
\hline 11 & & $x$ & $x$ & $x$ & $x$ & & & & 6 & 37 & 83.8 \\
\hline 8 & & $x$ & $x$ & & $x$ & & & & 6 & 37 & 83.8 \\
\hline 25 & $x$ & $x$ & $x$ & $x$ & & $x$ & $x$ & & 0 & 34 & 100.0 \\
\hline 25 & $x$ & $x$ & $x$ & $x$ & $x$ & $x$ & $x$ & & 0 & 36 & 100.0 \\
\hline 15 & \multirow[t]{5}{*}{$x$} & $x$ & & & & $x$ & $x$ & & 3 & 36 & 91.7 \\
\hline 7 & & $x$ & & & & $x$ & & & 5 & 34 & 85.3 \\
\hline 8 & & $x$ & & & & & $x$ & & 13 & 36 & 63.9 \\
\hline 2 & & & & & & & & \multirow[t]{8}{*}{$x$} & 7 & 35 & 80.0 \\
\hline 2 & & & & & $x$ & & & & 15 & 37 & 59.5 \\
\hline 19 & \multirow[t]{2}{*}{$x$} & $x$ & \multirow[t]{2}{*}{$x$} & \multirow[t]{2}{*}{$x$} & $x$ & \multirow{4}{*}{$x^{*}$} & $x$ & & 1 & 36 & 97.2 \\
\hline 14 & & & & & & & $x$ & & 1 & 36 & 97.2 \\
\hline 8 & Hahn-We & inheime & and Acke & hann's & ht elen & & & & $5 * *$ & 26 & 80.8 \\
\hline 2 & Whitten' & $\mathrm{TiO}_{2} \mathrm{a}$ & $\mathrm{d} \mathrm{K}_{2} \mathrm{O}$ or & & & & & & 6 & 37 & 83.8 \\
\hline 12 & $x$ & $x$ & $x$ & $x$ & $x$ & & & & $* *$ & 37 & $* *$ \\
\hline 14 & & & & & & $x$ & $x$ & & $* *$ & 36 & $* *$ \\
\hline
\end{tabular}

* includes $\mathrm{Mgt}$;** analyzed or also analyzed sequentially - see Table 5.

examine whether the available measured attributes permit these petrographically recognized and defined groups to be discriminated in a quantitative manner ( $c f .$, Klomínský, 1969; Rhodes, 1969). For this purpose two classes are considered: Class A representing the central granite (zones 1 and 2 of Mehnert) and Class B the border granite (zones 3 and 4 of Mehnert). It must be recognized that the analyzed samples were collected by different people from designated geographic localities; in consequence, the same specimens were not analyzed for each set of variables and local variability factors must unavoidably be included in, and partially confuse, the discriminants.

A computer program that can calculate sequential linear discriminant functions (Whitten, 1970 A) with up to 25 independent variables was employed to calculate several hundred discriminant functions with various combinations and subsets of the following variables:

a. Elevation and specific gravity.

b. 10 oxides (Whitten, Table 1) - because $\mathrm{Fe}_{2} \mathrm{O}_{3}, \mathrm{FeO}$, and $\mathrm{MgO}$ seem not to have good reproducibility, these oxides and the alkalis were treated separately for some discriminant functions.

c. 8 element analyses published by HahnWeinheimer and Ackermann (1967).

d. Normative values (calculated from the chemical analyses of Whitten, Table 1).

e. Modal values published by Rein (1961).

f. $\mathrm{K}_{2} \mathrm{O}$ and $\mathrm{Na}_{2} \mathrm{O}$ values from Mehnert and Willgallis (1961).

Table 4 shows some of the subsets of variables for which discriminant functions were calculated and the efficiency with which these functions separate the samples into the two classes A and B. For these calculations only the 37 localities listed in Table 1 were included so that less than 37 sample sites were used when data from HahnWeinheimer and Ackermann, Mehnert and Willgallis and/or Rein were included (these authors did not give analyses for all of the 37 locations in Table 1). 
Table 4 shows that use of all the variables* permits 100 per cent efficiency in discriminating the two classes. Specific gravity plus Rein's modal values used together achieve only 63.9 per cent efficiency. A combination of the norms and modes (with elevation and specific gravity), however, causes only 3 of the 36 sites to be misclassified. Use of Whitten's chemical analyses alone or of the norms alone is less efficient than use of the combination of norms and modes. Surprisingly, Mehnert and Willgallis' (1961) alkali values alone (80 per cent efficiency) are almost as efficient as Whitten's ten oxides (coupled with elevation and specific gravity) used together (81 per cent efficiency). The discriminant function calculated for the eight elements analyzed by Hahn-Weinheimer and Ackermann (1967) only misclassifies 5 of 26 samples (81 per cent efficiency).

The discriminant function can be visualized more clearly when represented in map form. As an example, the locations of correctly and incorrectly classified sample locations in subset 2 (Table 6) are shown in Figure $8 \mathrm{~A}$. In Figure $8 \mathrm{~B}$ one of the discriminant functions that is 100 per cent efficient (subset 8) is mapped to show the relative distance of each sample from the linear partition.

Effectiveness of discriminant functions can be considered differently. In many cases, the same (or even better) efficiency is achieved by use of only a small subset of the available variables $(c f$., Chayes and Velde, 1965). Table 5 illustrates some representative results produced by sequentially calculating the discriminant function for each subset of one variable, each possible subset of two variables, etc., in a total data array. For the available Malsburg Granite data, a single variable is commonly a very inefficient basis for a discriminant function but, in several cases, occasional pairs of variables are as efficient as, say, 8 or 14 variables used together. However, the

* Except that either Mehnert and Willgallis' or Whitten's alkali values only were included. »best» subsets selected in this manner are not always those that would be selected intuitively or on the basis of subjective geological experience (see Table 5).

It can be assumed that Rein's (1961) modes are good representations of the samples concerned but, as Table 4 shows, they are poor bases (63.9 per cent. efficient) for discrimination between Mehnert and Willgallis' two mapped zones (Classes A and B). This is particularly interesting because the mapped zones represent a summation of Rein's petrographic findings (modified, in certain cases by Mehnert and Willgallis' own investigations). Mehnert (personal communication) considered that Rein's results give the best reflection of the primary state of formation of the granite, whereas he thought that chemical analyses incorporate influences of secondary processes having no recognizable connection with the primary genesis. (For this reason, before making alkali analyses, Mehnert and Willgallis apparently discarded all samples which, in their opinion, contained secondary products).

It is possible that, in terms of their operational definitions, Mehnert and Willgallis misclassified some of the sample localities and, as a result, drew the boundary between the central and border granite zones incorrectly. If the boundary

TABLE 5

Examples of 'best' subsets of variables for the Malsburg Granite selected by sequential discriminant function analysis

\begin{tabular}{|c|c|c|c|c|c|}
\hline \multirow{2}{*}{$\begin{array}{l}\text { Data set } \\
\begin{array}{l}\text { Variables } \\
\text { included } \\
\text { in subset }\end{array}\end{array}$} & \multicolumn{2}{|c|}{$\begin{array}{l}\text { Whitten's } 10 \text { oxides } \\
\text { plus elevation and } \\
\text { specific gravity } \\
\mathrm{N}=37^{*}\end{array}$} & \multicolumn{3}{|c|}{$\begin{array}{l}\text { Hahn-Weinheimer and } \\
\text { Ackermann's } 8 \text { elements } \\
\qquad N=26^{*}\end{array}$} \\
\hline & $\begin{array}{c}\text { Number } \\
\text { Mis- } \\
\text { classified }\end{array}$ & Efficiency & Variables & $\begin{array}{l}\text { Number } \\
\text { Mis- } \\
\text { classified }\end{array}$ & Efficiency \\
\hline All 12 & 7 & $\begin{array}{c}81.08 \\
\text { Best' } P a\end{array}$ & $\begin{array}{l}\text { All } 8 . \\
\text { irs }\end{array}$ & 5 & 80.77 \\
\hline $\begin{array}{l}\mathrm{K}_{2} \mathrm{O}+\mathrm{TiO}_{2} \\
\mathrm{~K}_{2} \mathrm{O}+\mathrm{P}_{2} \mathrm{O}_{5}\end{array}$ & $\begin{array}{l}6 \\
8\end{array}$ & $\begin{array}{c}83.78 \\
78.38 \\
\text { Best' In }\end{array}$ & $\begin{array}{l}\mathrm{P}+\mathrm{Rb} \\
\mathrm{Ba}+\mathrm{Rb} \\
\text { lividual }\end{array}$ & $\begin{array}{l}5 \\
5\end{array}$ & $\begin{array}{l}80.77 \\
80.77\end{array}$ \\
\hline $\begin{array}{l}\text { Specific } \\
\text { gravity }\end{array}$ & 13 & 64.86 & $\mathrm{Ba}$ & 9 & 65.38 \\
\hline
\end{tabular}

* $\mathrm{N}$ is number of samples in whole set. 
TABLE 6

Malsburg Granite sample sites misclassified by linear discriminant functions using different data subsets; misclassified samples marked $x$

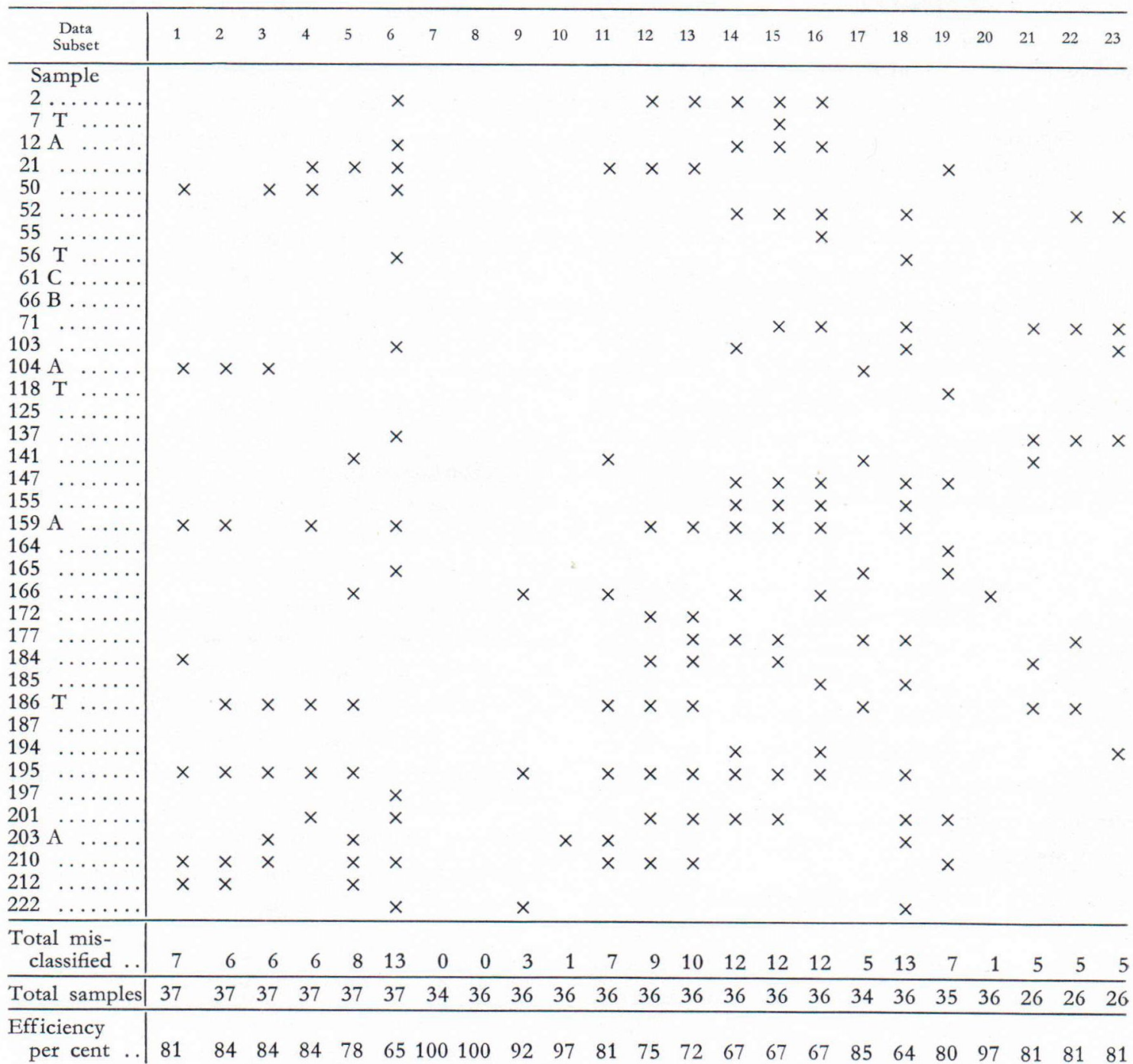

Identification of data subsets:

1 - all Whitten oxides + specific gravity + elevation

2 - all Whitten oxides + specific gravity

3 - all Whitten oxides except $\left(\mathrm{FeO}+\mathrm{Fe}_{2} \mathrm{O}_{3}+\mathrm{MgO}\right)+$ specific gravity

4 - Whitten $\mathrm{K}_{2} \mathrm{O}$ \& $\mathrm{TiO}_{2}$ only

5 - Whitten $\mathrm{K}_{2} \mathrm{O}+\mathrm{P}_{2} \mathrm{O}_{5}$ only

6 - Whitten specific gravity only

7 - Whitten oxides except alkalis + Mehnert and Willgallis alkalis $+{ }^{\top}$ Whitten norms except Mgt + Rein modes + specific gravity + elevation

8 - as 7 but Whitten alkalis in place of Mehnert and Willgallis alkalis

9 - all norms except Mgt + Rein modes + specific gravity + elevation

10 - all norms + Rein modes

11 - normative orthoclase and apatite only; 11, 12 , \& 13 'best' three pairs from all norms and all modes

12 - normative orthoclase and modal plagioclase only 
13 - normative orthoclase and modal K-feldspar only

14 - modal quartz and plagioclase; 14,15 , and 16 'best' three pairs from all modes

15 - modal K-feldspar and zircon

16 - modal plagioclase and biotite

17 - all norms except Mgt + specific gravity

18 - all modes + specific gravity

19 - Mehnert and Willgallis alkalis only

20 - as 8 without norms

21 - all eight Hahn-Weinheimer and Ackermann analyses

22 - $\mathrm{P}$ and $\mathrm{Rb} ; 22$ and 23 'best' two pairs from all variables in 21

$23-\mathrm{Ba}$ and $\mathrm{Rb}$

T samples identified by Mehnert as being transitional between Classes A and B

was correctly drawn (in terms of their operational definitions), these authors must have (appropriately) incorporated very important, subjectively-appraised, qualitative variables that are not reflected by any of the published data tables and which it would be difficult for other geologists to verify or compare with another complex. In Table 6 , the samples that were misclassified by a selection of the discriminant functions are listed; samples that appear repeatedly should be re-examined in terms of both Mehnert and Willgallis' original classification and the accuracy of the analytical data. Localities 159, 186, and 195 (and possibly 104) should be evaluated in this way ( $c f$., Fig. 8 A). Many of the 37 localities are classified correctly by all or most of the discriminant functions. Mehnert (personal communication) considered that four of the localities (numbers 7, 56, 118, and 186) used here are outer central granite transitional to border granite (see Fig. 8 B); although the discriminant functions commonly misclassify 186, all major functions correctly classify the other three localities as central granites (see Table 6). It can be seen from Table 6 that there are several other sample sites that are more liable to misclassification (on the basis of the available data) and which are, in this sense, truly transitional between Classes A and B.

Although not commonly measured, many textural, compositional, and structural characteristics of granites can be objectively estimated quantitatively and/or qualitatively in the field. However, because such measurements have not been made for the Malsburg Granite, these variables cannot be incorporated in statistical discriminant analyses. The chemical and normative variables that permitted efficient discrimination of the Malsburg Classes can only be measured in the laboratory. A lack of numerical data for those field observations used for classifying rock assemblages is not unusual, while extensive arrays of chemical analyses for the same rocks may not readily permit discrimination of traditional petrographic groups. For example, Chayes (1964) and Chayes and Velde (1965) discovered that $\mathrm{TiO}_{2}$ percentage is the only major oxide that efficiently discriminates between ocean-island and circumoceanic basalts. In such circumstances, in order that unequivocal quantitative discrimination may be made in the field during a mapping project, additional different criteria (e.g., textural characteristics, number and size of porphyroblasts, etc.) must be measured and mapped. If there is any basis for Mehnert's petrologically-significant model for the Malsburg Granite (as seems highly likely), there must be variables that could be measured in the field and be used as a basis for objective definition of his zones. In an economic situation, discovery of the few variables that can efficiently discriminate between commercially significant and unprofitable rock masses could greatly reduce the costs of exploration ( $c f$., Whitten, 1966 A). 


\section{Prediction models for the variability of the Malsburg Granite}

Predictor models have many uses for testing petrogenetic and search models for individual granitic bodies. Predictions, made on the basis of samples gathered from a single lithic unit, can be made without reference to the spatial locations of the specimens. Commonly, more useful models result from including the spatial coordinates; three types are considered here: (i) models without mapped results, (ii) trend-surface maps for single dependent variables, and (iii) Q-mode factor-analysis maps based on simultaneous use of numerous measured variables.

\section{Predication models without mapped results}

Some attributes are measured more precisely, accurately, and/or cheaply than others. As mentioned already, the variance of each variable in samples of a specified size and collected from one rock unit is, in general, different. Because of the large variance of some variables (and/or difficulties of measurement), direct estimates of their distribution within rock units are difficult. Table 7 shows that simple linear correlation of many pairs of variables is not likely to be useful for prediction purposes. However, it might be anticipated that such attributes could be predicted on the basis of more-easily-assayed variables.

TABLE 7

Correlation coefficients based on 36 of the sample locations listed in Table 1.

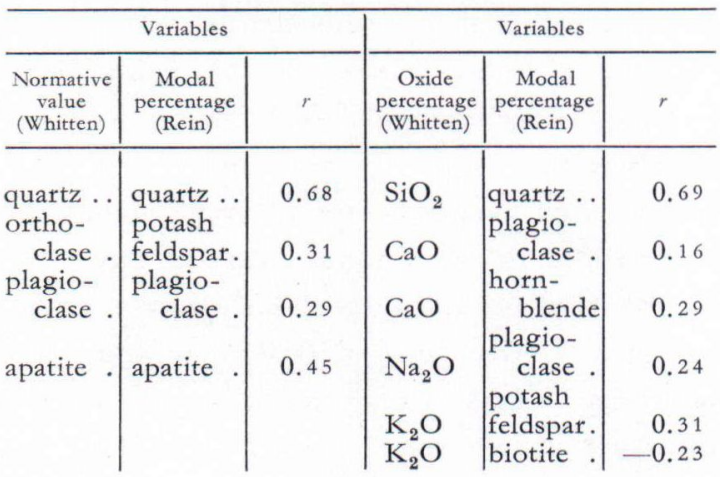

Vistelius (1962) demonstrated that the $\mathrm{P}_{2} \mathrm{O}_{5}$ content of some Tien Shan granitic rocks can be predicted with a simple linear model using modal quartz, potash feldspar, plagioclase, and mafic mineral percentages as independent variables. Similarly, Whitten $(1966,1968)$ demonstrated that sequential multiple linear regression can be used to "sort out» some of the interrelationships between chemical and specific gravity data for the Aulanko Granodiorite, Finland, and the Malsburg Granite. It seems probable that such prediction techniques could have considerable value for prospecting and evaluation in economic geology, in remotely-sensing the terrestrial surface from aircraft and satellites, and in a wide variety of petrological studies. However, at present, very little is known about the variance and interrelationships of the many hundreds of variables that can be measured for rock samples.

In the linear equation

$$
Y=a_{0}+a_{1} X_{1}+a_{2} X_{2}+a_{3} X_{3}+\ldots a_{13} X_{13}
$$

let $Y$ be $\mathrm{TiO}_{2}$ percentage and $X_{1}, \ldots X_{13}$ be specific gravity, nine other analyzed oxides, and the three spatial coordinates. Solving the equation by the method of least squares* and using the data for all thirteen »independent» variables available for the Malsburg Granite samples (Table 1), 86.97 per cent of the total variability of $\mathrm{TiO}_{2}$ can be predicted. However, it is instructive to examine the prediction equations when only a few windependent» variables are used. Table 8 shows that

$$
\mathrm{TiO}_{2}=a_{0}+a_{1}\left(\mathrm{SiO}_{2}\right)
$$

accounts for 75.53 per cent of the total sum of squares. Hence, for many purposes, prediction on the basis of $\mathrm{SiO}_{2}$ alone would be adequate and inclusion of specific gravity or the other

* The FORTRAN computer program prepared by Krumbein et al. (1964) was used for this purpose. As stated the model includes spatial coordinates and independent variables; by omitting these spatial variables a model without reference to location of the samples is involved. 
TABLE 8

'Best' predictions of $\mathrm{TiO}_{2}$ and $\mathrm{P}_{2} \mathrm{O}_{5}$ percentages and specific gravity for the Malsburg Granite using sequential linear regression analysis

\begin{tabular}{|c|c|c|c|c|c|c|c|c|}
\hline \multirow{3}{*}{$\begin{array}{c}\text { Number of } \\
\text { independent } \\
\text { variablestaken } \\
\text { at a time }\end{array}$} & \multirow{2}{*}{\multicolumn{2}{|c|}{$\begin{array}{c}\mathrm{TiO}_{2} \text { percentage }^{1} \\
N=37\end{array}$}} & \multirow{2}{*}{\multicolumn{2}{|c|}{$\begin{array}{c}\mathrm{P}_{2} \mathrm{O}_{5} \text { percentage }{ }^{1} \\
N=37\end{array}$}} & \multicolumn{4}{|c|}{ Specific Gravity } \\
\hline & & & & & \multicolumn{2}{|l|}{$N=37^{2}$} & \multicolumn{2}{|l|}{$N=36^{3}$} \\
\hline & $\begin{array}{l}\text { Independent } \\
\text { variables }\end{array}$ & $\begin{array}{c}\text { Sum of } \\
\text { squares } \\
\text { reduction } \\
\% *\end{array}$ & $\begin{array}{l}\text { Independent } \\
\text { variables }\end{array}$ & $\begin{array}{c}\text { Sum of } \\
\text { squares } \\
\text { reduction } \\
\% * *\end{array}$ & $\begin{array}{l}\text { Independent } \\
\text { variables }\end{array}$ & $\begin{array}{c}\text { Sum of } \\
\text { squares } \\
\text { reduction } \\
\% * * *\end{array}$ & $\begin{array}{l}\text { Independent } \\
\text { variables }\end{array}$ & $\begin{array}{l}\text { Sum of } \\
\text { squares } \\
\text { reduction } \\
\% * * * * \\
\end{array}$ \\
\hline 1 & $\begin{array}{l}\mathrm{SiO}_{2} \\
\mathrm{MgO} \\
\mathrm{P}_{2} \mathrm{O}_{5} \\
\end{array}$ & $\begin{array}{l}75.53 \\
47.31 \\
47.23\end{array}$ & $\begin{array}{l}\mathrm{SiO}_{2} \\
\mathrm{TiO}_{2} \\
\mathrm{Al}_{2} \mathrm{O}_{3} \\
\end{array}$ & $\begin{array}{l}56.34 \\
47.23 \\
42.32\end{array}$ & $\begin{array}{l}\mathrm{CaO} \\
\mathrm{FeO} \\
\mathrm{SiO}_{2} \\
\end{array}$ & $\begin{array}{l}37.76 \\
31.89 \\
18.64\end{array}$ & $\begin{array}{l}\mathrm{CaO} \\
\text { Norm. Qtz. } \\
\text { Norm. Anorth. \% } \\
\end{array}$ & $\begin{array}{l}38.97 \\
34.84 \\
33.86 \\
\end{array}$ \\
\hline 2 & $\begin{array}{l}V, \mathrm{SiO}_{2} \\
W, \mathrm{SiO}_{2} \\
\mathrm{SiO}_{2}, \mathrm{Fe}_{2} \mathrm{O}_{3}\end{array}$ & $\begin{array}{l}81.69 \\
79.28 \\
76.90\end{array}$ & $\begin{array}{l}\mathrm{SiO}_{2}, \mathrm{Al}_{2} \mathrm{O}_{3} \\
\mathrm{Al}_{2} \mathrm{O}_{3}, \mathrm{TiO}_{2} \\
\mathrm{SiO}_{2}, \mathrm{Na}_{2} \mathrm{O}\end{array}$ & $\begin{array}{l}62.57 \\
59.90 \\
59.37\end{array}$ & $\begin{array}{l}\mathrm{FeO}, \mathrm{CaO} \\
\mathrm{SiO}_{2}, \mathrm{CaO} \\
\mathrm{Fe}_{2} \mathrm{O}_{3}, \mathrm{CaO}\end{array}$ & $\begin{array}{l}43.11 \\
40.24 \\
40.13\end{array}$ & $\begin{array}{l}\mathrm{CaO} \text {, Hornbl. } \\
\text { Hornbl., Norm. } \\
\text { anorth. \% } \\
\mathrm{CaO} \text {, Qtz. } \\
\text { Qtz., Norm. } \\
\text { Anorth. \% } \\
\end{array}$ & $\begin{array}{l}51.13 \\
48.80 \\
48.31 \\
47.34 \\
\end{array}$ \\
\hline 3 & $\begin{array}{l}U, V, \mathrm{SiO}_{2} \\
V, \mathrm{SiO}_{2}, \mathrm{Na}_{2} \mathrm{O} \\
V, \mathrm{SiO}_{2}, \mathrm{Fe}_{2} \mathrm{O}_{3} \\
V, W, \mathrm{SiO}_{2}\end{array}$ & $\begin{array}{l}83.43 \\
82.48 \\
82.26 \\
82.24\end{array}$ & $\begin{array}{l}\mathrm{Al}_{2} \mathrm{O}_{3}, \mathrm{Fe}_{2} \mathrm{O}_{3}, \mathrm{FeO} \\
\mathrm{SiO}_{2}, \mathrm{Al}_{2} \mathrm{O}_{3}, \mathrm{Na}_{2} \mathrm{O} \\
\mathrm{SiO}_{2}, \mathrm{Al}_{2} \mathrm{O}_{3}, \\
\mathrm{Fe}_{2} \mathrm{O}_{3} \\
\mathrm{SiO}_{2}, \mathrm{Na}_{2} \mathrm{O}, \mathrm{K}_{2} \mathrm{O}\end{array}$ & $\begin{array}{l}65.54 \\
65.42 \\
64.60 \\
64.24\end{array}$ & $\begin{array}{l}\mathrm{SiO}_{2}, \mathrm{Fe}_{2} \mathrm{O}_{3}, \mathrm{CaO} \\
\mathrm{FeO}, \mathrm{CaO}, \mathrm{Na}_{2} \mathrm{O} \\
U, \mathrm{FeO}, \mathrm{CaO} \\
\mathrm{Fe}_{2} \mathrm{O}_{3}, \mathrm{CaO}, \mathrm{TiO}_{2}\end{array}$ & $\begin{array}{c}45.26 \\
44.28 \\
44.13 \\
44.11\end{array}$ & $\begin{array}{l}\mathrm{CaO}, \mathrm{P}_{2} \mathrm{O}_{5}, \\
\text { Hornbl. } \\
\mathrm{Fe}_{2} \mathrm{O}_{3}, \mathrm{CaO}, \\
\mathrm{Hornbl} \\
\mathrm{Fe}_{2} \mathrm{O}_{3}, \mathrm{CaO}, \mathrm{Qtz} . \\
\mathrm{MgO}^{\mathrm{MgOO}}, \\
\text { Hornbl. }\end{array}$ & $\begin{array}{l}53.40 \\
52.82 \\
52.75 \\
52.25\end{array}$ \\
\hline
\end{tabular}

1 Prediction based on all nine other oxides (Table 1), Specific Gravity, $U, V$, and $W$

2 Prediction based on all ten oxides (Table 1), $U, V$, and $W$

3 Prediction based on all ten Whitten's oxides, seven Rein's modes, 4 major Whitten's norms, and $W$

* Maximum with all 13 'independent' variables - 86.97 per cent.

** Maximum with all 13 'independent' variables -75.09 per cent.

*** Maximum with all 13 'independent' variables -53.47 per cent.

**** Maximum with all 22 'independent' variables -70.61 per cent.

$N=$ Number of samples available.

eight oxides would be redundant; that is, inclusion of a few oxides in addition to $\mathrm{SiO}_{2}$ adds little to predictive power.

Use of the linear equation for prediction of $\mathrm{P}_{2} \mathrm{O}_{5}$ permits 75.09 per cent of the variability to be accounted for when all the other variables are used. Use of $\mathrm{SiO}_{2}$ alone permits 56.34 per cent of the variability to be accounted for (Table 8).*

* This is a significant improvement over use of even the cubic trend surface (based on geographic coordinates and described in a subsequent section of this paper) which accounts for only 19.14 per cent of the total sum of squares (see Table 11). The three orthogonal spatial coordinates are identified as $U, V$, and $W$ (expressed in kilometers) in Table 8 and the remainder of this paper. For convenience, the axial origin was placed just north of the granite with $U$ increasing in a southwesterly, $V$ in a southeasterly, and $W$ in the upwards direction.
Intuitively, geologists have little basis for deciding whether these results for $\mathrm{TiO}_{2}$ and $\mathrm{P}_{2} \mathrm{O}_{5}$ are reasonable and common, or whether they are markedly dissimilar to those that would be found for the majority of granitoid masses. For specific gravity, however, many geologists would anticipate significant correlations with modal mineralogy. Dawson and Whitten (1962) and Whitten (1963 A, p. 111; 1966 A) suggested that specific gravity might be a more efficient variable for expressing the three-dimensional composition and variability of granitic masses than the customary modal variables. This contention was based on (i) the similarity of trend surfaces for specific gravity and modal variables (e.g., in the Lacorne, La Motte, and Preissac granitic complex, 
Quebec, Canada and the »older granite» of Donegal, Ireland), (ii) the fact that much larger specimens can be used for measuring specific gravity than are commonly used for modes or chemical analyses, so that the smallest levels of variance can be eliminated, and (iii) consideration of problems arising from the fact that modal data necessarily involve closed-number (percentage) arrays. Moore (1963) also demonstrated that strong correlation of specific gravity with modal quartz and feldspars for the Cartridge Pass pluton, Sierra Nevada, Calofornia, and concluded that the mineralogical zonation of the Arrow, Cartridge Pass, Lamarck, Paradise, and Spook silicic granodiorite plutons is accurately reflected by specific gravity. Peikert (1962; 1965) analyzed the three-dimensional variability of specific gravity and some modal variables in the
Glen Alpine stock, Sierra Nevada, California, but did not evaluate the correlation between these variables. However,in a similar three-dimensional study of the San Isabel Granite, Colorado, Whitten and Boyer (1964, Figs 7 and 8) presented data that strongly suggest significant correlations between specific gravity (for powdered rock samples) and weight percentages of various heavy-mineral fractions. Whitten (1968) also showed that for the Aulanko Granodiorite, Finland, use of the ten major oxides in a linear regression equation permits 94.83 per cent of the variability of specific gravity to be predicted.

Sequential linear regression analysis of the data given by Moore (1963, Tables 11, 12, 13, 24) for the Arrow, Cartridge Pass, and Spook plutons confirms that specific gravity is strongly correlated with the modal components (Table 9);

TABLE 9

'Best' predictions of specific gravity on the basis of modes of plutons in the Mount Pinchot Quadrangle, California (data from Moore, 1963) using sequential linear regression analysis

\begin{tabular}{|c|c|c|c|c|c|c|c|c|}
\hline \multirow{2}{*}{$\begin{array}{c}\text { Number of } \\
\text { modal } \\
\text { variablestaken } \\
\text { at a time }\end{array}$} & \multicolumn{2}{|l|}{$\begin{array}{l}\text { Arrow Pluton } \\
\quad N=18\end{array}$} & \multicolumn{2}{|l|}{$\begin{array}{l}\text { Bullfrog Pluton } \\
\qquad N=27\end{array}$} & \multicolumn{2}{|c|}{$\begin{array}{l}\text { Cartridge Pass Pluton } \\
\qquad N=45\end{array}$} & \multicolumn{2}{|l|}{$\begin{array}{l}\text { Spook Pluton } \\
\qquad N=21\end{array}$} \\
\hline & $\begin{array}{c}\text { Independent } \\
\text { variables }\end{array}$ & $\begin{array}{c}\text { Sum of } \\
\text { squares } \\
\text { reduction } \\
\% *\end{array}$ & $\begin{array}{l}\text { Independent } \\
\text { variables }\end{array}$ & $\begin{array}{c}\text { Sum of } \\
\text { squares } \\
\text { reduction } \\
\% *\end{array}$ & $\begin{array}{l}\text { Independent } \\
\text { variables }\end{array}$ & $\begin{array}{c}\text { Sum of } \\
\text { squares } \\
\text { reduction } \\
\% *\end{array}$ & $\begin{array}{l}\text { Independent } \\
\text { variables }\end{array}$ & $\begin{array}{c}\text { Sum of } \\
\text { squares } \\
\text { reduction } \\
\% * \\
\end{array}$ \\
\hline 1 & $\begin{array}{l}\text { Plagioclase } \\
\text { K-feldspar } \\
\text { Pyroxene } \\
\end{array}$ & $\begin{array}{l}61.28 \\
51.74 \\
27.85\end{array}$ & $\begin{array}{l}\text { Biotite } \\
\text { Color index } \\
\text { Nonopaque acces- } \\
\text { sories }\end{array}$ & $\begin{array}{r}10.23 \\
7.91 \\
7.86 \\
\end{array}$ & $\begin{array}{l}\text { Hornblende } \\
\text { Color index } \\
\text { Biotite }\end{array}$ & $\begin{array}{l}76.89 \\
75.29 \\
65.24\end{array}$ & $\begin{array}{l}\text { Hornblende } \\
\text { Color index } \\
\text { K-feldspar }\end{array}$ & $\begin{array}{l}53.18 \\
33.38 \\
30.64 \\
\end{array}$ \\
\hline 2 & $\begin{array}{l}\text { Plagioclase, biotite } \\
\text { Plagioclase, } \\
\text { color index } \\
\text { Quartz, } \\
\text { K-feldspar }\end{array}$ & $\begin{array}{r}72.35 \\
68.35 \\
68.05\end{array}$ & $\begin{array}{l}\text { Opaque accesso- } \\
\text { ries, color index } \\
\text { Perthite, biotite } \\
\text { Biotite, opaque } \\
\text { accessories }\end{array}$ & $\begin{array}{r}19.50 \\
16.45 \\
14.39 \\
\end{array}$ & $\begin{array}{l}\text { K-feldspar, } \\
\text { hornblende } \\
\text { Plagioclase, } \\
\text { hornblende } \\
\text { Plagioclase, } \\
\text { color index }\end{array}$ & $\begin{array}{l}80.72 \\
80.35 \\
78.65 \\
\end{array}$ & $\begin{array}{l}\text { K-feldspar, } \\
\text { hornblende } \\
\text { K-feldspar, } \\
\text { color index } \\
\text { Plagioclase, } \\
\text { hornblende }\end{array}$ & $\begin{array}{l}65.99 \\
61.56 \\
59.55 \\
\end{array}$ \\
\hline 3 & $\begin{array}{l}\text { Plagioclase, bio- } \\
\text { tite, opaque ac- } \\
\text { cessories } \\
\text { Plagioclase, } \\
\text { opaque accesso- } \\
\text { ries, color index } \\
\text { Plagioclase, bio- } \\
\text { tite, nonopaque } \\
\text { accessories }\end{array}$ & $\begin{array}{c}74.18 \\
72.60\end{array}$ & $\begin{array}{l}\text { Perthite, opaque } \\
\text { accessories, } \\
\text { color index } \\
\text { Quartz, opaque } \\
\text { accessories, } \\
\text { color index } \\
\text { Perthite, biotite, } \\
\text { opaque accesso- } \\
\text { ries }\end{array}$ & $\begin{array}{r}30.04 \\
27.64 \\
-23.25\end{array}$ & $\begin{array}{l}\text { Quartz, } \\
\text { K-feldspar, } \\
\text { hornblende } \\
\text { Plagioclase, bio- } \\
\text { tite, hornblende } \\
\text { K-feldspar, } \\
\text { plagioclase, } \\
\text { hornblende }\end{array}$ & $\begin{array}{r}81.53 \\
881.45 \\
81.26\end{array}$ & $\begin{array}{l}\text { K-feldspar, horn- } \\
\text { blende, non- } \\
\text { opaque accesso- } \\
\text { ries } \\
\text { K-feldspar, } \\
\text { hornblende, } \\
\text { color index } \\
\text { K-feldspar, bio- } \\
\text { tite, hornblende }\end{array}$ & $\begin{array}{l}68.49 \\
67.87 \\
67.73\end{array}$ \\
\hline
\end{tabular}

* Maximum with all 'independent' modal variables - 78.91\% for Arrow, 37.28 \% for Bullfrog, $82.29 \%$ for Cartridge Pass, and $71.81 \%$ for Spook Pluton.

$N=$ Number of samples available. 
TABLE 10

'Best' predictions of specific gravity for the Climax Stock Granodiorite, Nevada, using sequential linear regression analysis

\begin{tabular}{|c|c|c|c|c|c|c|}
\hline \multirow{2}{*}{$\begin{array}{l}\text { Number of } \\
\text { variablestaken } \\
\text { at a time }\end{array}$} & \multicolumn{2}{|l|}{$\begin{array}{c}\text { Data subset } 1 * \\
\quad N=14\end{array}$} & \multicolumn{2}{|l|}{$\begin{array}{c}\text { Data subset } 2^{* *} \\
\quad N=20\end{array}$} & \multicolumn{2}{|l|}{$\begin{array}{c}\text { Data subset } 3^{* * *} \\
\quad N=16\end{array}$} \\
\hline & $\begin{array}{c}\text { Independent } \\
\text { variables }\end{array}$ & $\begin{array}{c}\text { Sum of } \\
\text { squares } \\
\text { reduction } \\
\% \\
\end{array}$ & $\begin{array}{c}\text { Independent } \\
\text { variables }\end{array}$ & $\begin{array}{l}\text { Sum of } \\
\text { squares } \\
\text { reduction } \\
\% \\
\end{array}$ & $\begin{array}{l}\text { Independent } \\
\text { variables }\end{array}$ & $\begin{array}{c}\text { Sum of } \\
\text { squares } \\
\text { reduction } \\
\% \\
\end{array}$ \\
\hline 1 & $\begin{array}{l}\mathrm{K}_{2} \mathrm{O} \\
\mathrm{CaO} \\
\mathrm{MgO}\end{array}$ & $\begin{array}{l}53.48 \\
39.23 \\
21.28\end{array}$ & $\begin{array}{l}\text { Magnetics } \\
\text { Elevation } \\
\text { Chlorite }\end{array}$ & $\begin{array}{l}20.95 \\
20.26 \\
14.99\end{array}$ & $\begin{array}{l}\text { Elevation } \\
\text { Magnetics } \\
\text { Susceptibility }\end{array}$ & $\begin{array}{l}31.88 \\
18.45 \\
16.27\end{array}$ \\
\hline 2 & $\begin{array}{l}\mathrm{SiO}_{2}, \mathrm{CaO} \\
\mathrm{Na}_{2} \mathrm{O}, \mathrm{K}_{2} \mathrm{O} \\
\mathrm{CaO}, \mathrm{Na}_{2} \mathrm{O}\end{array}$ & $\begin{array}{l}72.04 \\
71.42 \\
70.10\end{array}$ & $\begin{array}{l}\text { Elevation, magnetics } \\
\text { Elevation, plagioclase } \\
\text { Elevation, biotite }\end{array}$ & $\begin{array}{l}48.92 \\
28.86 \\
28.27\end{array}$ & $\begin{array}{l}\text { Elevation, magnetics } \\
\text { Elevation, chlorite } \\
\text { Susceptibility, magnetics }\end{array}$ & $\begin{array}{l}49.90 \\
38.81 \\
32.88\end{array}$ \\
\hline 3 & $\begin{array}{l}\text { Elevation, } \mathrm{MgO}, \mathrm{K}_{2} \mathrm{O} \\
\text { Elevation, } \mathrm{Na}_{2} \mathrm{O}, \mathrm{K}_{2} \mathrm{O} \\
\text { Elevation, } \mathrm{SiO}_{2}, \mathrm{~K}_{2} \mathrm{O}\end{array}$ & $\begin{array}{l}88.41 \\
87.38 \\
87.29\end{array}$ & $\begin{array}{l}\text { Elevation, quartz, } \\
\text { magnetics } \\
\text { Elevation, plagioclase, } \\
\text { magnetics } \\
\text { Elevation, biotite, } \\
\text { magnetics }\end{array}$ & $\begin{array}{l}52.02 \\
51.43 \\
50.26\end{array}$ & $\begin{array}{l}\text { Elevation, chlorite, } \\
\text { magnetics } \\
\text { Susceptibility, chlorite, } \\
\text { magnetics } \\
\text { Elevation, plagioclase, } \\
\text { magnetics }\end{array}$ & $\begin{array}{l}57.39 \\
53.73 \\
51.68\end{array}$ \\
\hline
\end{tabular}

1 Eight variables - elevation, $\mathrm{SiO}_{2}, \mathrm{Al}_{2} \mathrm{O}_{3}$, total iron, $\mathrm{MgO}, \mathrm{CaO}, \mathrm{Na}_{2} \mathrm{O}$, and $\mathrm{K}_{2} \mathrm{O}$; maximum sum of squares with all variables 94.68 per cent.

2 Seven variables - elevation, plagioclase, K-feldspar, quartz, biotite, and chlorite volume per cent, and weight per cent of magnetics; maximum sum of squares with all variables 55.80 per cent.

3 Eight variables - elevation, magnetic susceptibility, plagioclase, K-feldspar, quartz, biotite, and chlorite volume per cent, and weight per cent of magnetics; maximum sum of squares with all variables 77.19 per cent.

$N$ - number of samples in subset.

these granites have mean color indices of 13.3, 9.7, and 8.4, respectively. However, Table 9 also shows that this relationship does not hold for Bullfrog pluton (mean color index 3.0). For a small set of data for the Climax Stock granodiorite, Nevada (analyses from Houser and Poole, 1959, and Izett, 1960), the linear correlation coefficients between specific gravity and each of the major-oxide and modal variables is less than 0.5 (Whitten, 1963, p. 112). This relationship is reflected by Table 10 (all variables taken one at a time and even when three modal variables are taken at a time). However, the oxides taken two or more at a time and large groups of modal variables both permit reasonable predictions of specific gravity with these data. Cain (1964) also showed on the basis of 53 samples that modes have little value in predicting specific gravity of the Newingham Granodiorite, Wisconsin.
For the Malsburg Granite samples, Table 8 shows that only 53.47 per cent of their specific gravity variation can be predicted on the basis of all ten oxides, and three spatial coordinates. Although only accounting for 37.76 per cent, it is surprising that $\mathrm{CaO}$ provides the best prediction on the basis of a single oxide. In an attempt to find those factors that control specific gravity in the Malsburg Granite, Rein's (1961) modal values and the four main normative components were included with the chemical analyses before recomputing the linear regression relationships. $\mathrm{CaO}$ remains the »best» single variable (Table 8) and the »best» pair of variables is $\mathrm{CaO}$ with modal hornblende; modal hornblende with normative anorthite percentage gives the »nextbest» pair. Such relationships can be rationalized in terms of petrography although they are dis- 
similar to those for, say, the Aulanko Granodiorite.

These results for samples from different granite masses are perplexing. It is not known, for example, what characteristics cause specific gravity to be predictable in some granites, but not in others. Lack of predictability may result from poor chemical analyses, clerical errors, or real differences in composition between the material used for chemical or modal analysis and that used for density determination. The latter could readily occur if variances are large at the level of small samples and analyses are made for part of a larger sample weighed for specific gravity measurement. Until more is known about the factors controlling such correlations, predictions cannot be extended to specimens from the sampled population of an unstudied granite complex that has not already been subjected to preliminary study (let alone be extended to most possible granite target populations).

\section{Trend-surface maps for single dependent variables}

It must be recognized that in computing trend components many assumptions are made about the data. Baird, et al., (1964, 1965) considered the significance of individual chemical analyses before attempting to map the chemical composition and variability of a granite pluton. It is well known that each variable has a different variance in samples of a given size and that the components of variance at different levels of sampling vary in a different complex manner for each variable. These problems, which significantly affect the manner in which sampling should be undertaken, are additional to those concerning the analytical accuracy for each selected sample. Very little is known about the levels of variance in different plutons. Baird, et al. referred to the Rattlesnake Pluton, California and it is probable that equally complex, but different, relationships occur in other plutons ( $c f$., Rhodes, 1969).

Once a set of analyses has been acquired for the sampled population it is customary to assess their pattern of spatial variability; it is commonly implicitly (but erroneously) assumed that the pattern is that of the target population too. The variability can be assessed subjectively by drawing manual contours although, because there is no information about the behaviour of the variables between the actual sample sites, an infinite number of dissimilar maps can be drawn (Whitten, 1966 B). Figure 9 illustrates two possible subjective contour maps for 114 unpublished analyses of $\mathrm{K}_{2} \mathrm{O}$ for the »older granite» of Donegal, Eire. Neither map violates the data. The method permits the geologist to incorporate appropriate subjective geological factors in the final map. Commonly, however, one of the many quantitative objective methods of depicting the spatial variability of mapped variables has been used. Polynomial trend-surface analysis permits the regional and local components of variability of a set of samples to be mapped separately; it is illustrated here. Other linear (e.g., double Fourier Series) and nonlinear trend surfaces could be used, although selection of one of these models would be more appropriate when the nature and underlying petrogenetic causes of the spatial variability are more clearly understood.

Table 11 lists the proportions of the total sums of squares associated with polynomial trend components (calculated with the computer program published by Whitten et al., 1965) for Mehnert and Willgallis' (1961) alkalis, Whitten's chemical analyses (Table 1), and HahnWeinheimer and Ackermann's (1967) analyses of eight elements.

For the Malsburg Granite data, the low degree trend surfaces based on $U$ and $V$ only are almost all associated with small sums of squares predicted (Table 11); Sr and $\mathrm{Ba}$ are exceptions. This implies that, for most variables, the local deviations are large by comparison with the degree one, two, and three regional gradients and that, for each variable, the variability of the samples analyzed has a complex local pattern. The regional gradients are shown in Figures 10, 11, and 12. For Whitten's chemical analyses and 

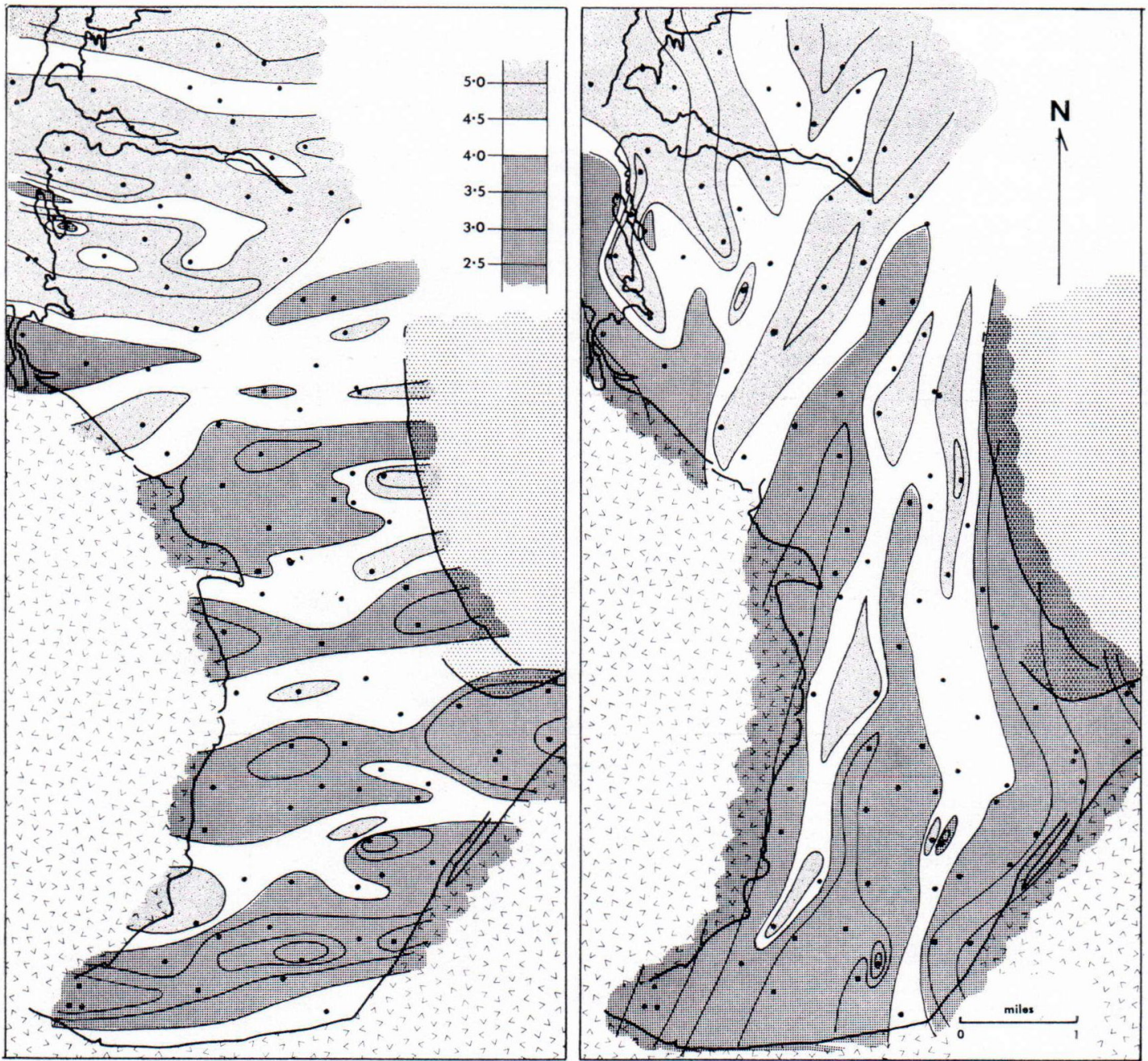

Fig. 9. Variation of $\mathrm{K}_{2} \mathrm{O}$ weight percentage in the 'older granite' of the Bunbeg-Thorr area, Donegal, Eire; based on analyses of samples from the 114 localities indicated. The two maps are different but equally-valid, manually contoured representations of the same original data. After Whitten $1966 \mathrm{~B}$.

specific gravity only 37 sample sites are available so that surfaces of higher degree than third (with 10 coefficients) should not be calculated, despite the values shown in Table 11 and regardless of the proportion of the variability accounted for by fourth and higher degrees. For the trace elements (Fig. 12), 64 samples were used and the degrees of freedom make it reasonable to consider trend surfaces up to the fifth degree (which require 21 coefficients in the polynomial equation). For the alkalis, maps (Fig. 11) are presented for all three independent sets of chemical analyses; degree 3 or degree 5 surfaces are illustrated depending on the number of degrees of freedom associated with each data set. Because each group of alkali analyses would be accepted by many petrographers as an adequate representation of the pluton and serve as a basis for petrogenetic conclusions, it is instructive to compare and contrast these three pairs of maps thoroughly.

Without very careful evaluation, such trend 
TABle 11

Percentages of total sums of squares associated with polynomial trend surfaces for the Malsburg Granite

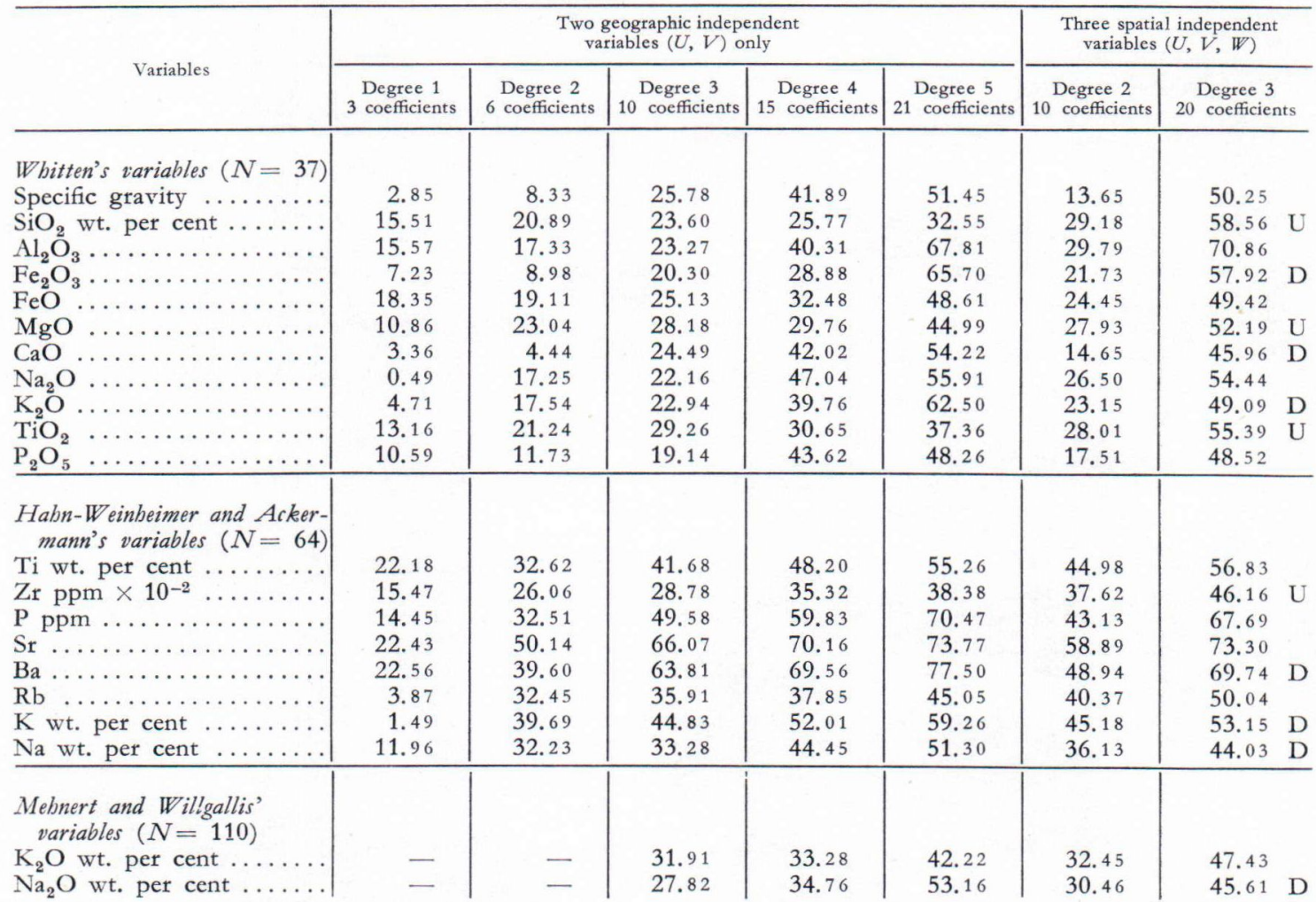

$N=$ number of samples; $\mathrm{U}=$ sum of squares for $U, V, W$ degree 3 appreciably greater than for $U, V$ degree 5 ; and $\mathrm{D}$ sum of squares appreciably smaller.

maps could readily give erroneous concepts about the sampled and the target populations. Special problems arise at the boundaries of the data sets, in dataless areas, and with spurious extreme values when fourth and higher degree surfaces are used. Some of these problems can be circumvented by using piecewise polynomial surfaces of low degree ( $c f$., Whitten, $1966 \mathrm{~A}$, Crain and Bhattacharyya, 1967) although much depends upon the objectives of the surface fitting. However, the whole subject of the merits, demerits, and interpretation of trend-surface components is beyond the scope of this article and is being made the subject of a separate paper. Confidence levels can be associated with each trend component (see Dawson and Whitten, 1962, p. 8; Whitten, 1963; Chayes, 1970) and, when considered separately, most of the linear, quadratic, and cubic components for Whitten's chemical analysis data (Figs. 10 and 11) have no significant confidence level. The situation is demonstrated very clearly by scanning the $z^{2}$-arrays which can be computed by using orthogonal polynomials for the irregularly-spaced data (Crain and Bhattacharyya, 1967; Whitten, 1970B); for these data, trivial values occupy the top left corner of the $z^{2}$-arrays in most cases. The 'best' array is that for $\mathrm{TiO}_{2}$, while $\mathrm{SiO}_{2}, \mathrm{Al}_{2} \mathrm{O}_{3}, \mathrm{Fe}_{2} \mathrm{O}_{3}$, $\mathrm{FeO}, \mathrm{MgO}, \mathrm{K}_{2} \mathrm{O}$ and $\mathrm{P}_{2} \mathrm{O}_{5}$ have one or two reasonably strong linear terms surrounded by triv- 


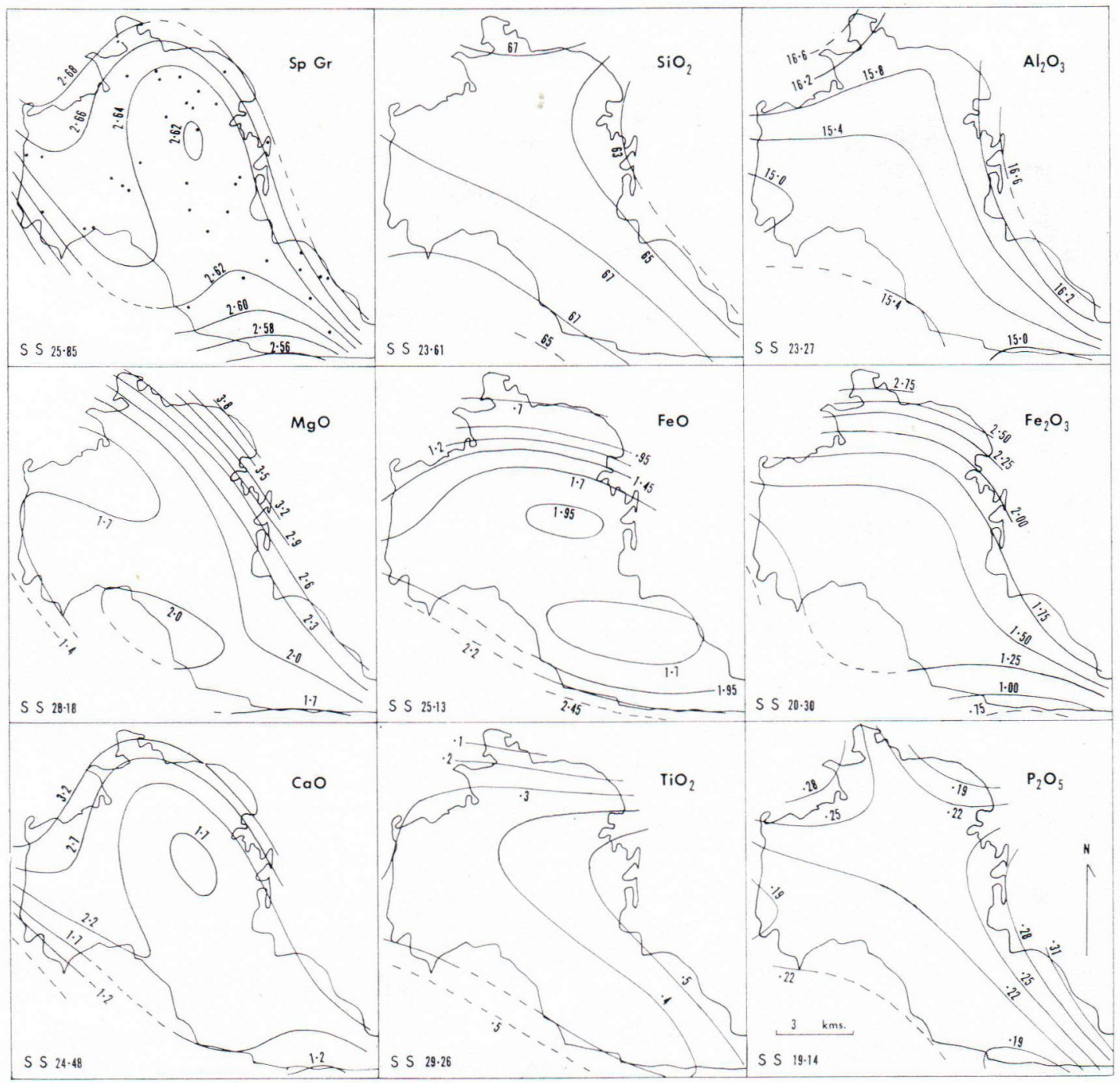

Fig. 10. Degree 3 polynomial trend surfaces for the Malsburg Granite computed for $U$, $V$, and the analyses listed in Table 1. The 37 sample localities are shown on the specific gravity map and SS indicates the percentage of the total sum of squares associated with each surface.

ial terms in the $z^{2}$-array (Table 12). Such evidence confirms that the available data provide only a poor basis for evaluating the spatial variability of the sampled population (let alone the target population).

Weight percentages have been used for these maps because it is customary to use this unit in petrology although, in mapping spatial variability within a rock unit, it is more significant to use weights per unit volume. Density is known for the 37 analyzed samples, so the oxides can be expressed in $\mathrm{gm} / 100 \mathrm{cc}$; although no longer percentages, the restraints of closed-number tables still apply to such data, which yield slightly different trend components and different correlation coefficients.

Because the samples were collected from sites with a vertical range of some 620 meters, poly- 


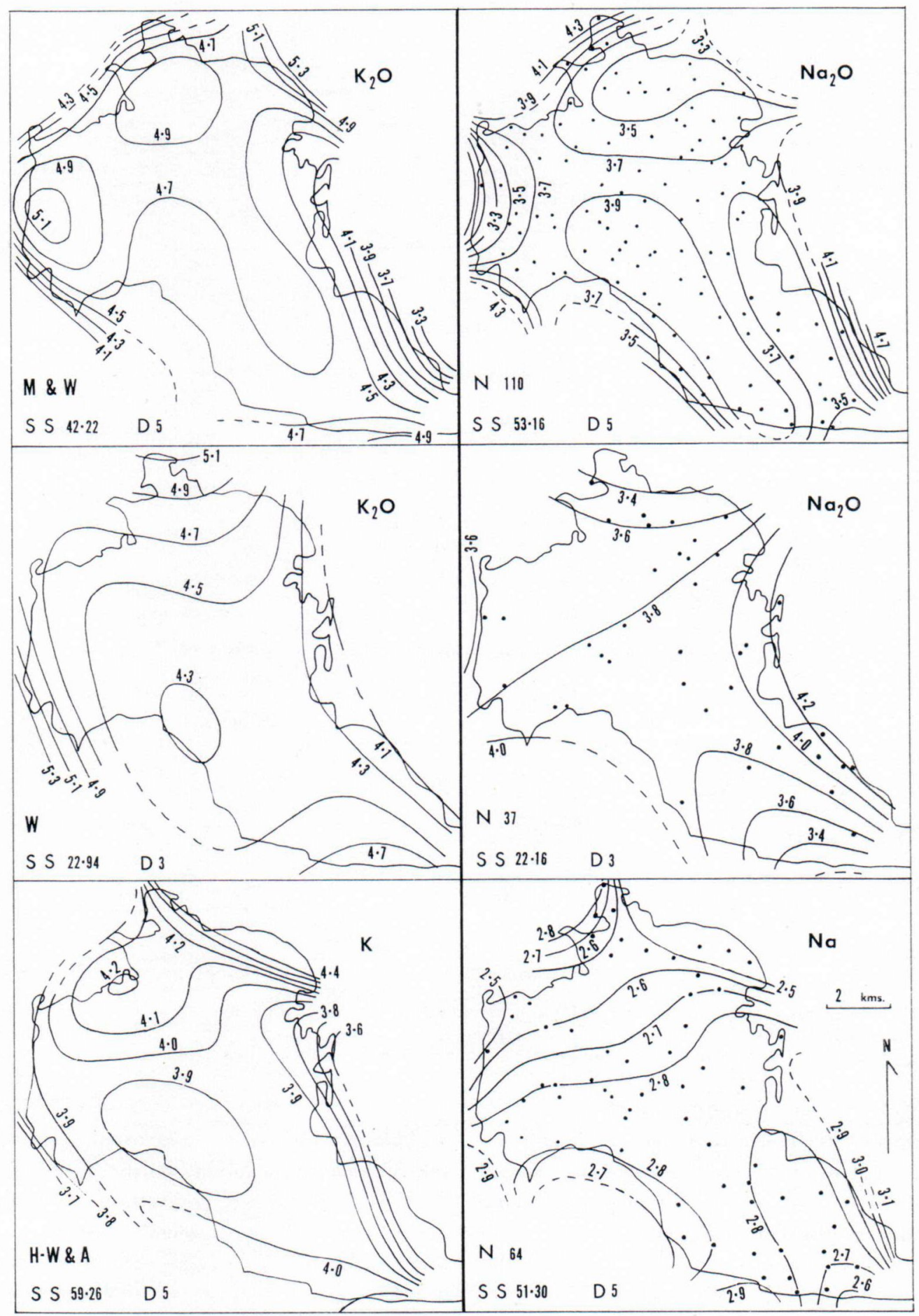

Fig. 11. Polynomial trend surfaces for the Malsburg Granite computed for $U$, $V$, and the three independent sets of alkali analyses by Mehnert and Willgallis ( $M \& W)$, Whitten (W), and HahnWeinheimer and Ackermann (H-W \& A). Degree 5 (D 5) and degree 3 (D 3) surfaces are illustrated and SS refers to the percentage of the total sum of squares associated with each surface. $N$ is the number of sample localities used for each pair of maps (the actual sites are shown on the $\mathrm{Na}_{2} \mathrm{O}$ or $\mathrm{Na}$ map). 


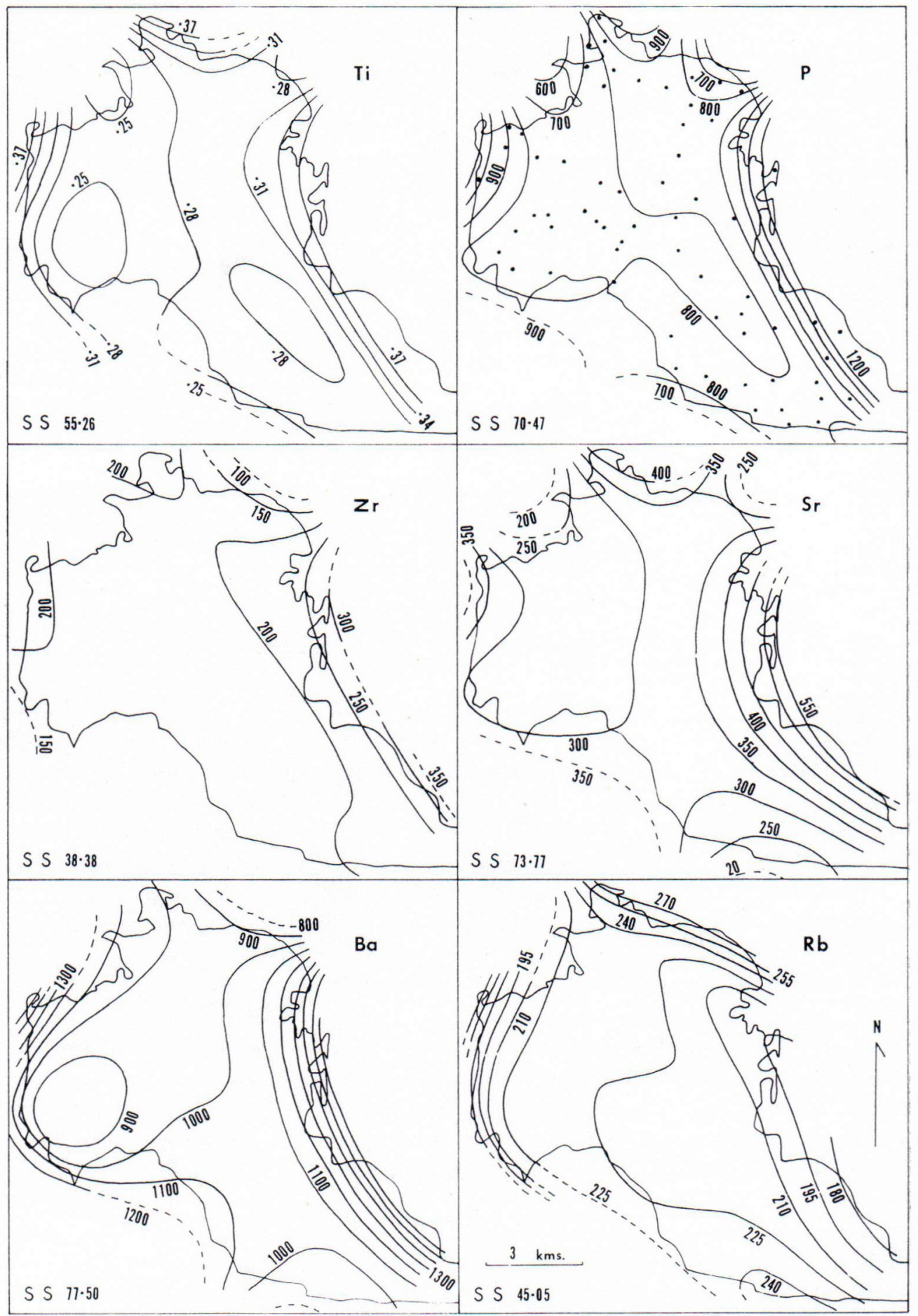

Fig. 12. Degree 5 polynomial trend surfaces for the Malsburg Granite computed for $U, V$, and the 64 sets of analyses from Hahn-Weinheimer and Ackermann. The 64 sample localities are shown on the $\mathrm{P}$ map. SS indicates the percentage of the total sum of squares associated with each surface. 
TABLE 12

Examples of $z^{2}$-arrays for the Whitten chemical analyses $(\mathrm{N}=37)$; limit of complete trend indicated by the line: $\mathrm{TiO}_{2}$ and $\mathrm{FeO}$ weight percentages

\begin{tabular}{|c|c|c|c|c|c|c|c|c|}
\hline & & & & & $\mathrm{TiO}_{2}$ & & & \\
\hline & 0.04 & 0.02 & 0.01 & 0.00 & 0.00 & 0.01 & 0.01 & 0.01 \\
\hline 0.02 & 0.01 & 0.00 & 0.00 & 0.02 & 0.01 & 0.00 & 0.01 & . \\
\hline 0.01 & 0.02 & 0.00 & 0.00 & 0.00 & 0.16 & 0.02 & . & . \\
\hline 0.01$]$ & 0.00 & 0.00 & 0.00 & 0.08 & 0.07 & . & . & \\
\hline$\overline{0.00}$ & 0.00 & 0.01 & 0.02 & 0.01 & . & . & & \\
\hline 0.01 & 0.00 & 0.01 & 0.00 & . & . & & & \\
\hline 0.01 & 0.00 & 0.00 & . & . & & & & \\
\hline 0.03 & 0.03 & . & . & & & & & \\
\hline 0.04 & . & . & & & & & & \\
\hline · & . & & & & & & & \\
\hline & & & & & $\mathrm{FeO}$ & & & \\
\hline & 0.26 & 0.00 & 0.41 & 0.49 & 1.06 & 0.01 & 0.15 & 0.20 \\
\hline 1.55[ & 0.00 & 0.17 & 0.02 & 0.30 & 0.19 & 0.56 & 0.19 & . \\
\hline$\overline{0.07}$ & 0.01 & 0.01 & 0.06 & 0.01 & 1.67 & 0.31 & . & . \\
\hline 0.00 & 0.14 & 0.06 & 0.27 & 0.78 & 1.50 & . & . & \\
\hline 0.07 & 0.04 & 0.00 & 0.01 & 0.46 & . & . & & \\
\hline 0.08 & 0.34 & 0.07 & 0.03 & . & . & & & \\
\hline 0.01 & 0.05 & 0.04 & . & . & & & & \\
\hline 0.17 & 0.41 & . & . & & & & & \\
\hline 0.45 & . & . & & & & & & \\
\hline . & . & & & & & & & \\
\hline
\end{tabular}

nomial hypersurfaces (up to the third degree) were also calculated with the computer program published by Peikert (1963). Inclusion of elevation $(W)$ as an independent variable results in marked increases in the total sums of squares associated with equations of the same degree (Table 11). Peikert (e.g., 1962, 1965) and Whitten (e.g., 1962) suggested that the increased proportions of the total sums of squares associated with third degree polynomials when elevation is included (in addition to geographic coordinates), imply that there is a significant amount of vertical variability within the sampled populations studied. For some granites, it was suggested that the vertical rates of change are greater than those in the horizontal plane. It is important to recognize, however, that degree-three $U V W$ hypersurfaces involve 20 coefficients and that it is possibly more appropriate to compare them with the degree $5 U V$-surfaces which have approximately the same number of coefficients.

The restraints already discussed that apply to interpretation of the $U V$-maps obviously apply to the $U V W$-trend components and make it difficult to draw meaningful conclusions for the present data set. The degree $5 U V$-surfaces and degree $3 U V W$-hypersurfaces (Table 11) show that inclusion of elevation yields important sums of squares increases for $\mathrm{SiO}_{2}, \mathrm{MgO}, \mathrm{TiO}_{2}$, and $\mathrm{Zr}$ and important decreases for $\mathrm{Fe}_{2} \mathrm{O}_{3}, \mathrm{CaO}$, Whitten's $\mathrm{K}_{2} \mathrm{O}, \mathrm{Ba}, \mathrm{Na}$, and Mehnert and Willgallis' $\mathrm{Na}_{2} \mathrm{O}$. For the variables showing increases, there is possibly important vertical variability. By contrast, the decreases suggest variables for which vertical variability is relatively less important and for which a greater proportion of the total variability of the sampled population is accounted for by more complex areal variability patterns.

To illustrate the effect of including elevation, horizontal sections through the polynomial hypersurfaces at 725 meters above sea level (roughly the mean elevation of the sample sites) for the three sets of alkali analyses are given in Figure 13. These maps should be compared and contrasted with those in Figure 11 for the same 


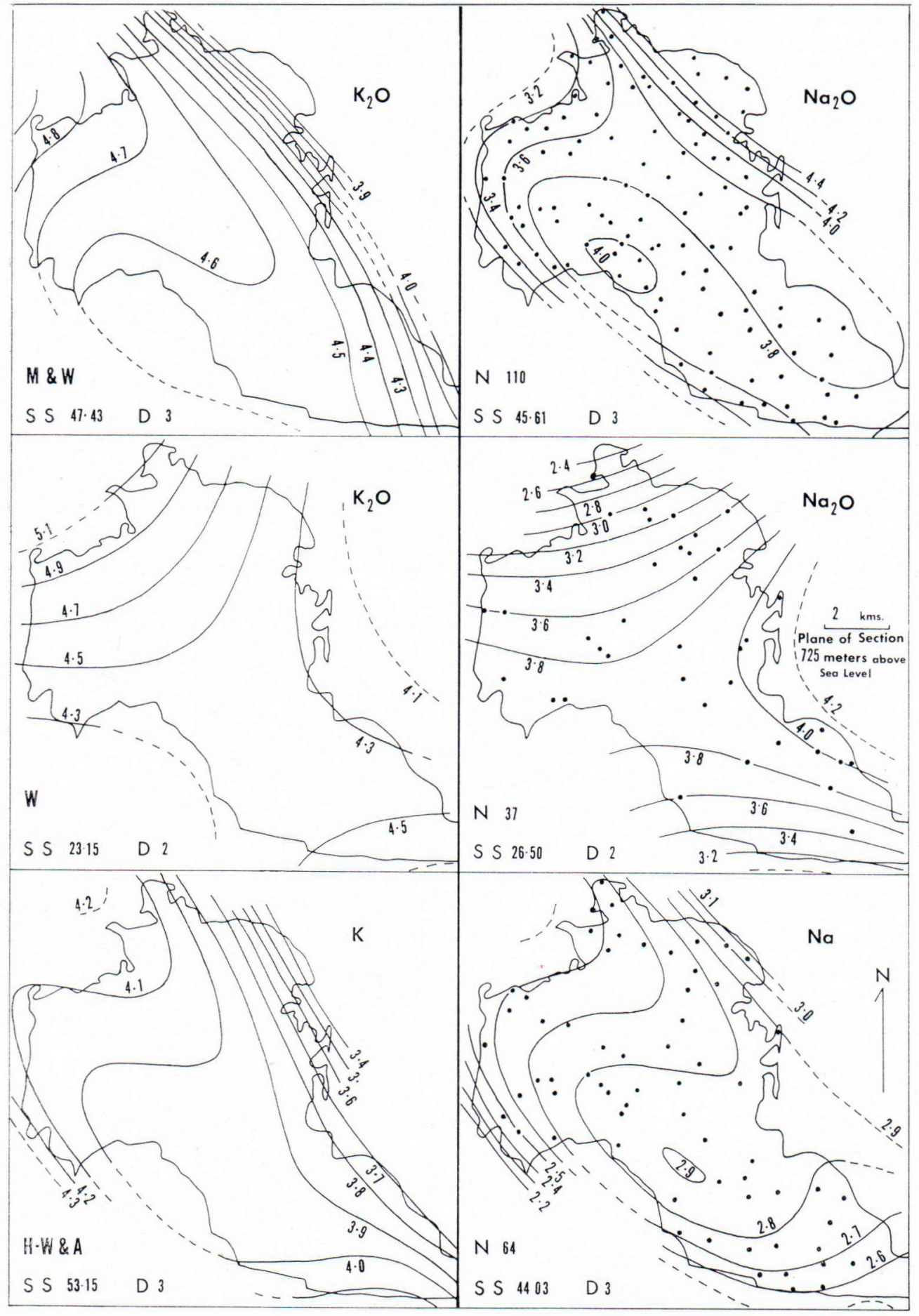

Fig. 13. Horizontal sections (at 725 meters above sea level) through polynomial hypersurfaces for $U, V, W$, and the three independent sets of alkali analyses by Mehnert and Willgallis (M \& W), Whitten (W), and Hahn-Weinheimer and Ackermann (H-W \& A). Degree 3 (D 3) and degree 2 (D 2) surfaces are illustrated and SS refers to the percentage of the total sum of squares associated with each hypersurface. $\mathrm{N}=$ number of sample localities used for each pair of maps (the actual sites are shown on the $\mathrm{Na}_{2} \mathrm{O}$ or $\mathrm{Na}$ map). 
data with elevation ignored. Of course, Figure 13 reflects vertical as well as horizontal extrapolations because the 725 meter plane is either above or below the sampled surface (ground level) over most of the map area.

The limitations of polynomial trend surfaces (particularly when interpolation and extrapolation are involved) have been widely discussed (e.g., Whitten, 1966 A, Merriam and Cocke, 1967, Chayes, 1970) A wide range of problems that affect the usefulness of individual surfaces has been recognized (e.g., selection of the trend, evaluation of deviations, boundary effects, spacing of data points, change of variance over map area, etc.). The limited amount of data available for the Malsburg Granite makes it uncertain (or even unlikely) whether Figures 10, 11, 12, and 13 provide a realistic picture of the regional variation of either the sampled or the target population.* Even if high confidence could be associated with the trend components, statistical inferences cannot be made about the target population on the basis of trend components; substantive geological reasoning can be used, but this (as in most other petrographic studies) is fraught with immense problems because so little is known about the levels of variance of the several variables involved. Also, it would be difficult to integrate a generalized picture of granite variability on the basis of separate maps of 19 different variables. A multivariate approach, permitting simultaneous consideration of some, or all, of the measured variables, would have distinct advantages. Such a method is outlined in the next section.

\section{Mapping several variables simultaneously}

In a preceding section attempts were made to determine the efficiency with which the available quantitative data for the sampled populations permit retrieval of Mehnert and Willgallis' (1961)

* For this purpose, the target population is defined as all those hand-sample size samples that theoretically comprise the whole mapped extent of the Malsburg Granite. mapped zones of the Malsburg Granite. An alternative approach is to use Q-mode factorvector analysis to detect, emphasize, and map the natural relationships between the available samples. In Q-mode factor analysis, $n$ significant factors are selected and the specimens that most closely correlate with each of the $n$ factors are found. Each other sample is then expressed numerically as proportions of the $n$ samples chosen to represent each of the $n$ factors. Maps can be prepared for each factor by plotting and contouring the numerical values for each specimen. The mathematical bases for such analyses were restated by Imbrie (1963) and Krumbein and Graybill (1965, pp. 368, 402).

Garrett (1967) published the computer program (limited to use with 100 samples 25 variables) used in the present work. The program permits data for each variable to be transformed into a $0-100$ scale so that each variable has an equal weight in the Q-mode analysis.** The

TABLE 13

Eigenvalues of some sample correlation matrices used for Q-mode factor analysis of the Malsburg Granite. Data $\log _{10}$ transformed before factor computation.

\begin{tabular}{|c|c|c|c|c|c|c|}
\hline \multirow[b]{2}{*}{ Factor } & \multicolumn{2}{|c|}{ Data subset (i) } & \multicolumn{2}{|c|}{ Data subset (ii) } & \multicolumn{2}{|c|}{$\begin{array}{c}\text { Data subset (ii) } \\
\text { with elevation } \\
\text { included }\end{array}$} \\
\hline & $\begin{array}{l}\text { Eigen- } \\
\text { value }\end{array}$ & $\begin{array}{c}\text { Cumula- } \\
\text { tive } \% \text { of } \\
\text { com- } \\
\text { munality } \\
\text { over } 36 \\
\text { factors }\end{array}$ & $\begin{array}{l}\text { Eigen- } \\
\text { value }\end{array}$ & $\begin{array}{l}\text { Cumula- } \\
\text { tive } \% \text { of } \\
\text { com- } \\
\text { munality } \\
\text { over } 64 \\
\text { factors }\end{array}$ & $\begin{array}{l}\text { Eigen- } \\
\text { value }\end{array}$ & $\begin{array}{c}\text { Cumula- } \\
\text { tive } \% \text { of } \\
\text { com- } \\
\text { munality } \\
\text { over } 64 \\
\text { factors }\end{array}$ \\
\hline $1 \mathrm{st}$ & 31.316 & 87.0 & 57.429 & 89.7 & 56.287 & 87.9 \\
\hline 2 nd $\ldots$ & 1.647 & 91.6 & 3.360 & 95.0 & 3.083 & 92.8 \\
\hline 3rd ... & .735 & 93.6 & 1.825 & 97.8 & 2.173 & 96.2 \\
\hline 4 th $\ldots$ & .573 & 95.2 & .755 & 99.0 & 1.402 & 98.3 \\
\hline 5 th $\ldots$ & .431 & 96.4 & .258 & 99.4 & .539 & 99.2 \\
\hline 6 th ... & .337 & 97.3 & .204 & 99.7 & .213 & 99.5 \\
\hline 7 th $\ldots$ & .200 & 97.9 & .126 & 99.9 & .175 & 99.8 \\
\hline 8 th $\ldots$ & .192 & 98.4 & .043 & 100.0 & .093 & 99.9 \\
\hline 9 th $\ldots$ & .140 & 98.8 & .000 & 100.0 & .036 & 100.0 \\
\hline
\end{tabular}

** Data normalization is necessary when major and trace components are used together, but it is questionable whether equal weight should be given to each variable. If analytical accuracy is not the same for all variables, some would favor giving extra weight to the more accurate ( $c f$. , Rhodes, 1969); more complete variance information for each variable (for samples of the size analyzed) might justify assigning unequal weights to variables. 
number of factors adequate to describe all of the samples is commonly decided on the basis of the size of the eigenvalues of the sample correlation matrix; three representative sets of eigenvalues are listed in Table 13. Maps were prepared for several data subsets on the basis of two, three, or four factors. However, Table 13 shows that one factor accounts for an overwhelming proportion of the total variability; analogous (or even more marked) situations occur for the other data subsets tested. Thus, for the present data for the sampled population of the Malsburg Granite, it appears that use of two factors provides an adequate representation of their spatial variability.

Slightly dissimilar results are obtained when different subsets of the measured data are used. Three of the many subsets examined are described here, viz:

(i) 25 variables for 36 specimens: specific gravity, 10 Whitten's chemical analyses, 7 Rein's modal values, and 7 normative values.

(ii) 8 variables for 64 samples: Hahn-Weinheimer and Ackermann's chemical analyses.

(iii) 7 variables for 100 samples: Rein's modal values.

Each subset represents a different sampled population. Whitten's chemical analyses and subsets (ii) and (iii) were also re-run with elevation included as an extra variable.

Figure $14 \mathrm{~A}$ is based on subset (i) and the zonation from northeast to southwest is clear, although there are significant differences and anomalies when these zones are compared with the subdivisions of Mehnert and Willgallis(1961). Because it was possible that either the chemical components or the modes might have been controlling this map pattern (Fig. $14 \mathrm{~A}$ ), these groups of variables were analyzed separately; the resulting maps (Figs. $14 \mathrm{C}$ and $14 \mathrm{E}$ ) show that, for both groups of variables (combined with elevation as an additional variable), this sampled population yields patterns remarkably similar to Figure $14 \mathrm{~A}$. For the modal map (Fig. $14 \mathrm{E}$ ), specimens 52, 177, and 195 are very anomalous in terms of the regional pattern of variability. Specimen 195 (and to a lesser extent 177) are also anomalous in the oxide map (Fig. $14 \mathrm{C}$ ).

The effect of elevation as an additional variable is appreciable. Figure 14 B shows the Q-mode map for Hahn-Weinheimer and Ackermann's analyses of eight variables for 64 samples (subset ii); the same data together with elevation are the basis of Figure 14 D. Although these maps have analogies, dissimilarities in the central and southeastern areas indicate that there is significant chemical variability in the limited vertical dimension exposed and represented by this sampled population. In these two maps, specimens 52, 118, and 187 are anomalous (but 177 is not); specimen 195 was not included in this subset.

Figure $14 \mathrm{~F}$ is based on 100 of Rein's modes and the elevations of each sample site (subset iii); the 36 specimens used for Figure $14 \mathrm{E}$ are all included together with 64 other samples chosen (with the aid of a random number table) from the 110 samples analyzed by Mehnert and Willgallis. Much of the complexity near the southwest margin of the granite in Figure $14 \mathrm{~F}$ occurs in areas that are dataless for Figure $14 \mathrm{E}$. Geologically, it would seem to be significant that, when the data used for Figure $14 \mathrm{~F}$ are represented by three factors, the highs are accounted for by two separate factors. The high on the eastern margin (Fig. 14 F) is due to factor 2 and that at the western margin to factor 3; the small high at the south is produced by a combination of factors 2 and 3. Specimens 52 and 177 have very small values in Figure $14 \mathrm{~F}$ by comparison with neighboring specimens, although 47(immediately southwest of 52) has an almost identical value to 52 . This suggests that similar rock composes 47 and 52 and that it is different from the rock of surrounding areas, rather than that the modal analyses (and chemical analyses in Figure 14 D) are in error. 


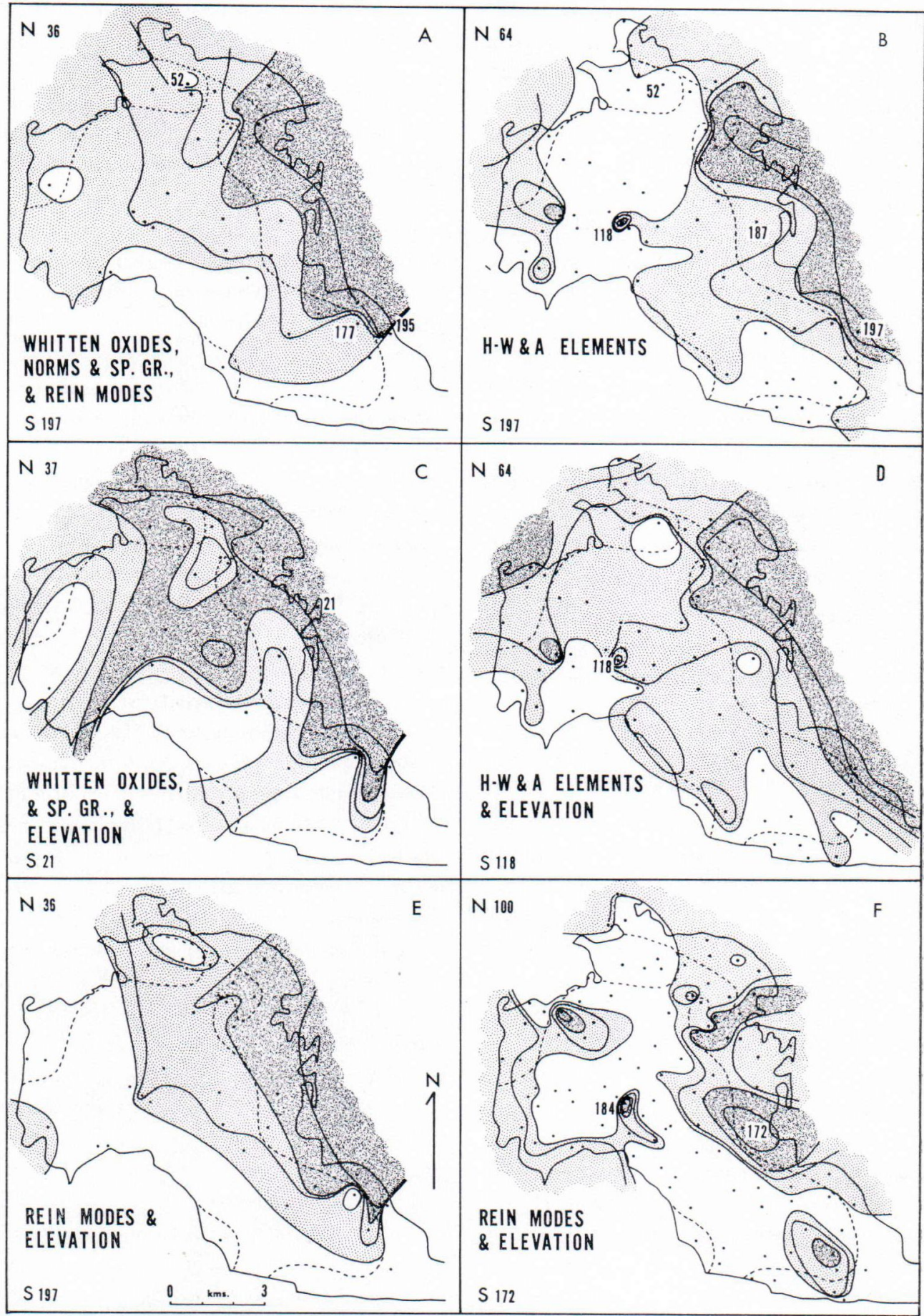

Fig. 14. Q-mode factor-analysis maps for the Malsburg Granite. S = the sample that represents the first Q-mode factor for the data used. $\mathrm{N}=$ the number of samples used (actual sites shown by dots and the 11 samples discussed in text are identified by number). Data $\log _{10}$ transformed before factor computation. 
The six maps in Figure 14 were manually contoured and quite different contour configurations could be drawn without violation of the data (cf., Fig. 9); the information contoured in these Q-mode maps could have been smoothed by trend surface methods. In an analysis of the Malsburg Granite, or discussion of the petrogenetic development of the pluton, the detailed similarities and differences shown by the six maps need to be examined in detail. Despite local differences, the marked similarity of the regional zonation shown by all six maps is impressive. The results presented earlier in this paper (e.g., discriminant analyses, correlations, etc.) had suggested that the available variables do not strongly support the zonation proposed by Mehnert and Willgallis. However, Figure 14 seems to suggest that, considered in a quantitative multivariate framework, zonation is real.

Because there are six different maps in Figure 14 , it remains to be determined which is the »best» approximation of the actual zonation that occurs in the sampled populations. The answer is not clear. Further numerical analysis may indicate the answer, but it seems more likely that critical re-examination of the outcrops in the field in the light of Figure 14 would throw significant light on the problem. It is geologically important to elicit more information about the levels of variance for the several variables in order to permit more-realistic subjective extrapolation of the results to the target population. Probably a subset of the many variables actually used and a selection of currently unmeasured variables (e.g., textural characteristics) would be more appropriate for defining the zonation actually present. Work is proceeding to identify such subsets of variables and to determine whether the same variables are equally useful in mapping the internal variability of other lithic units.

\section{Concluding statement}

Considerably more attention needs to be given to the significance of collected data and to the nature of the internal variability of granitic plutons and other lithic units. Study of the independent sets of analyses for the Malsburg Granite suggests that great care needs to be used in basing conclusions upon any single set of published analyses. In most published studies, insufficient is known about the levels of variance of the several analyzed variables and about the precise mode of sampling that was used; as a result, generalizations about the spatial variability of a complex become hazardous. In the absence of much more complete variance information than is commonly available, it is commonly difficult to assess the significance of a trend surface in terms of the actual spatial variability of the whole lithic unit.

Multivariate Q-mode maps, in which a large number of dissimilar variables can be considered simultaneously, appear to offer significant advantages in defining the spatial variability of sampled populations of granitic plutons and other rock bodies. Because each variable included in the analysis has, in general, a different pattern and amount of variance, some variables are undoubtedly sampled more appropriately than others. Intuitively, it seems reasonable to anticipate that Q-mode maps based on many variables will permit the gross variability of a sampled population for a lithic unit to be assessed with greater confidence than is possible with monovariate maps. However, insufficient emphasis is currently given to the fact that all such mapping techniques relate to a sampled population whereas, in most cases, the geologist wishing to draw petrogenetic conclusions is interested in a target population that is quite distinct from the sampled population for which data happen to be available.

Unfortunately, at this time, it is not known how representative the Malsburg Granite and its variability are. The pattern of variability of a granite mass needs to be known with accuracy in order to provide sound bases for quantitative petrogenetic models. With current knowledge of the thermodynamic factors underlying magmatic 
and metamorphic crystallization phenomena, it will soon be possible to develop quantitative computer-based nonlinear models for the petrogenesis and three-dimensional compositional variability of simple granitic masses. It would be unfortunate if such models are available before sufficient is known about actual granitic complexes to test and refine the computer-based theoretical petrogenetic predictions.

This paper is offered as a progress report. It is hoped that it will demonstrate that, in spite of the analytical technology and ability currently available (cf., Baird, et al., 1967, Chappell, 1966, Rhodes, 1970), for petrology as a whole, there is a tremendous lack of knowledge about commonly-measured variables of granitic masses. Petrographers commonly find very great significance in many other textural, mineralogical, and compositional variables than those discussed specifically in this paper; for these, precise operational definitions must be developed to permit measurement, mapping, and communication. It is quite possible that some of these unnumbered and unmeasured variables, in addition to (or in place of) some, or all, of those considered in this paper, might be critical in establishing an adequate quantitative basis for testing petrogenetic models. Adequate description of a lithic unit is extremely important but is not an end in itself. Significant description is a necessary step in establishing the validity of petrogenetic models.

Acknowledgements - Field work expenses in 1962 and the cost of the chemical analyses recorded in Table 1 were met from National Research Foundation Grant G-19633. Many ideas and techniques used in this paper were developed in the course of work under National Aeronautics and Space Administration Research Grant NGR-14-007-027. Drs. W. Zimmerle and H. Ackermann gave very useful assistance during the initial stages of field work. Through extensive correspondence at an early stage of this project, Prof. K. R. Mehnert kindly provided much very useful information about the Malsburg Granite.

\section{REFERENCES}

Baird, A. K., McIntyre, D. B., \& Welday, E. E., (1967) Geochemical and structural studies in batholithic rocks of southern California: Part II Sampling of the Rattlesnake Mountain Pluton for chemical composition, variability, and trend analysis: Bull. geol. Soc. Am., v. 78, pp. 191-222.

-, -, -, \& MAdLeM, K. W., (1964) Chemical variations in a granitic pluton and its surrounding rocks: Science, N.Y., v. 146 , pp. $258-259$.

Barthel, F., and Mehnert, K. R., (1970) Die Verteilung von Uran und Thorium im Malsburger Granit (als Beispiel einer granitischen Differentiationsserie): Neues Jb Miner. Abh., v. 114, pp. 18-47.

CAIN, J. A., (1964) Areal variability of specific gravity data from a granodiorite pluton: Am. J. Sci., v. 262, pp. $532-540$.

Chappell, B. W., (1966) Petrogenesis of the granites at Moonbi, New South Wales: Unpublished Ph. D. thesis, Australian National University.

Chayes, F., (1964) A petrographic distinction between Cenozoic volcanics in and around the open oceans: J. geophys. Res., v. 69, pp. 1573-1588.

- (1970) On deciding whether trend surfaces of progressively higher order are meaningful: Bull. geol. Soc. Am., v. 81, pp. 1273-1278.
— and Velde, D., (1965) On distinguishing basaltic lavas of circum-oceanic and oceanic-island type by means of discriminant functions: Am. J. Sci., v. 263, pp. $206-222$.

Crain, I. K., and Bhattacharyya, B. K., (1967) Treatment of non-equispaced two-dimensional data with a digital computer: Geoexploration, v. 5, pp. 173-194.

Dawson, K. R., and Whitren, E. H. T., (1962) The quantitative mineralogical composition and variation of the Lacorne, La Motte, and Preissac granitic complex, Quebec, Canada: J. Petrology, v. 3, pp. 1-37.

Garretr, R. G., (1967) Two programs for the factor analysis of geologic and remote-sensing data: NASA Res. Grant NGR-14 007-027, Northwestern Univ. Report 12, pp. $1-99$.

Griffiths, J. C., (1962) Statistical methods in sedimentary petrography: in Milner, H. B., Sedimentary Petrography Vol. I, Macmillan Co., New York, pp. pp. $565-609$.

Hahn-Weinheimer, P., and Ackermann, H., (1963) Quantitative röntgenspektral-analytische Bestimmung von Kalium, Rubidium, Strontium, Barium, Titan, Zirkonium und Phosphor: Z. analyt. Chem., v. 194, pp. $81-101$. 
_, - , (1967) Geochemical investigation of differentiated granite plutons of the Southern Black Forest - II. The zoning of the Malsburg Granite pluton as indicated by the elements titanium, zirconium, phosphorus, strontium, barium, rubidium, potassium and sodium: Geochim. cosmochim. Acta, v. 31, pp. 2197 $-2218$.

Houser, F. N., and Poole, F. G., (1959) »Granite» exploration hole, Area 15, Nevada Test Site, Nye County, Nevada - Interim Report, Part A, Structural, petrographic, and chemical data: U.S. geol. Surv. open-file report TEM-836 A.

Imbrie, J., (1963) Factor and vector analysis programs for analyzing geologic data: Off. Naval Res. Geog. Branch Tech. Report 6, ONR Task no. 389-135, 83 pp.

Izetт, G. A., (1960) »Granite» exploration hole, Area 15, Nevada Test Site, Nye County, Nevada - Interim report, Part C, Physical properties. Trace elements memorandum report 836 C: U.S. geol. Surv. open-file report TEM-836C.

Klomínskx́, J., (1969) Krkonošsko-jizerský granitoidní masív: Sborn. geol. Věd, Ser. G, v. 15, 133 pp.

Krumbein, W. C., Benson, B. T., \& Hempkins, W. B., (1964) Whirlpool, a computer program for "sorting out» independent variables by sequential multiple linear regression: Off. Naval Res., Geog. Branch, Tech. Report 14, ONR Task No. 389-135, 49 pp.

- and Graybill, F. A., (1965) An introduction to statistical models in geology: McGraw-Hill Book Co., New York, 475 pp.

Leible, O., (1959) Die Verteilung der Radioaktivität, der Thorium- und Urangehalte im Malsburggranit (Südschwarzwald): Z. Erzbergb. Metallhütt Wes., v. 12 , pp. $234-237$.

Mehnert, K. R., (1960) Zur Geochemie der Alkalien im tiefen Grundgebirge: Beitr. Miner. Petrogr., v. 7, pp. $318-339$.

- (1963) Petrographie und Abfolge der Granitisation im Schwarzwald. IV: Neues Jb. Miner. Abh., v. 99, pp. $161-199$.

- and Willgallis, A., (1957) Zum Alkalihaushalt der Granitisation im Schwarzwald an Hand flammenphotometrischer Reihenanalysen: Neues Jb. Miner. Abh., v. 91, pp. 104-130.

-, -, (1961) Die Alkaliverteilung im Malsburger Granit (Südschwarzwald): Jh. geol. Landesamt Baden-Württ., v. 5 , pp. $117-39$.

Merriam, D. F., \& Cocke, N. C., (1967) (Editors): Computer applications in the earth sciences: Colloquium on trend analysis: Computer Contrib. geol. Surv. Kansas, no. 12, 62 pp.
Moore, J. G., (1963) Geology of the Mount Pinchot Quadrangle Southern Sierra Nevada, California: Bull. U.S. geol. Surv., 1130, 152 pp.

Peikert, E. W., (1962) Three-dimensional specific gravity variation in the Glen Alpine Stock, Sierra Nevada, California: Bull. geol. Soc. Am., v. 73, pp. $1437-42$.

- (1963) IBM 709 program for least-squares analysis of three-dimensional geological and geophysical observations: Off. Naval Res., Geog. Branch, Tech. Report No. 4, ONR Task No. 389-135, 72 pp.

- (1965) Model for three-dimensional mineralogical variation in granitic plutons based on the Glen Alpine Stock, Sierra Nevada, California: Bull. geol. Soc. Am., v. 76, pp. $331-48$.

ReIN, G., (1955) Modalbestand und Intrusionsform eines Granitplutons (Malsburggranit, Schwarzwald): Fortschr. Miner., v. 33, p. 145.

- (1961) Die quantitativ-mineralogische Analyse des Malsburger Granitplutons und ihre Anwendung auf Intrusionsform und Differentiationsverlauf: Jh. geol. Landesamt Baden-Württ., v. 5, pp. 53-115.

Rhodes, J. M., (1969) The application of cluster and discriminatory analysis in mapping granite intrusions: Lithos, v. 2, pp. 223-37.

- (1970) The geochemistry of a granite-gabbro association: Unpub. Ph. D. thesis, Australian National University.

Schröder, E., (1929) Über Aufbau und Alter des Blauenmassivs im südlichen Schwarzwald: Mitt. bad. geol. Landesanst., v. 11, pp. 65-89.

Vistelius, A. B., (1962) Phosphorus in granitic rocks of central Tien Shan: Geochemistry, 1962, pp. 131-51.

Whitten, E. H. T., (1960) Quantitative evidence of palimpsestic ghost-stratigraphy from modal analysis of a granitic complex: Int. geol. Congr. XXI Copenhagen, Pt. 14, pp. 182-93.

- (1961) Quantitative areal modal analysis of granitic complexes: Bull. geol. Soc. Am., v. 72, pp. 1331-60.

- (1962) Areal variability of alkalis in the Malsburg Granite, Germany: Neues Jh. Miner. Mh., v. 9, pp. $193-200$.

- (1963 A) Application of quantitative methods in the geochemical study of granite massifs: in Studies in analytical geochemistry (edit. D. M. Shaw), Spec. Public. Roy. Soc. Canada, 6, pp. 76-123.

- (1963 B) A reply to Chayes and Suzuki: J. Petrology, v. 4 , pp. $313-6$.

- (1966 A) The general linear equation in prediction of gold content in Witwatersrand rocks, South Africa: J1. S. Afr. Inst. Min. Metall. (Symposium on mathematical statistics and computer applications in ore valuation), pp. $124-41$. 
- (1966 B) Quantitative models in the economic evaluation of rock units: illustrated with the Donegal granite and the gold-bearing Witwatersrand conglomerates: Trans. Instn. Min. Metall., v. 75 B, pp. $181-98$.

- (1968) О ДИСПЕРСИИ НЕКОТОРЫХ ПРИЗНАКОВ ГРАНИТНЫХ ПОРОД: in Questions in mathematical geology (edit. V. A. Steklova), Academy Sciences U.S.S.R., Lenin Mathematical Institute, Leningrad, pp. $240-52$.

- $(1970 \mathrm{~A}) \mathrm{A}$ sequential linear discriminant analysis program for geological and remotely-sensed data: NASA Res. Grant NGR-14 007-027, Northwestern Univ. Report 22, 22 pp.

- (1970 B) Orthogonal polynomial trend surfaces for irregularly-spaced data: Bull. Internat. Assoc. Math. Geol., v. 2, pp. $141-52$.
— \& Boyer, R. E., (1964) Process-response models for the San Isabel Granite, Colorado, based on heavy mineral content: Bull. geol. Soc. Am., v. 75, pp. 841 -62 .

-,Krumbein, W. C., Waye, I., \& Beckman, W. A., Jr., (1965) A surface-fitting program for areally-distributed data from the earth sciences and remote sensing: NASA Contr. Rept. CR-318, 146 pp.

Willgallis, A., (1970) Zur Mikrosondenanalyse der U-Th-Minerale im Malsburger Granit: Neues Jb Miner. Abh., v. 114, pp. $48-60$.

Zimmerle, W., (1958) Der Malsburgpluton im südwestlichen Schwarzwald: Jh. geol. Landesamt BadenWürtt., v. 3, pp. $81-122$.

Manuscript received, May 19, 1971. 

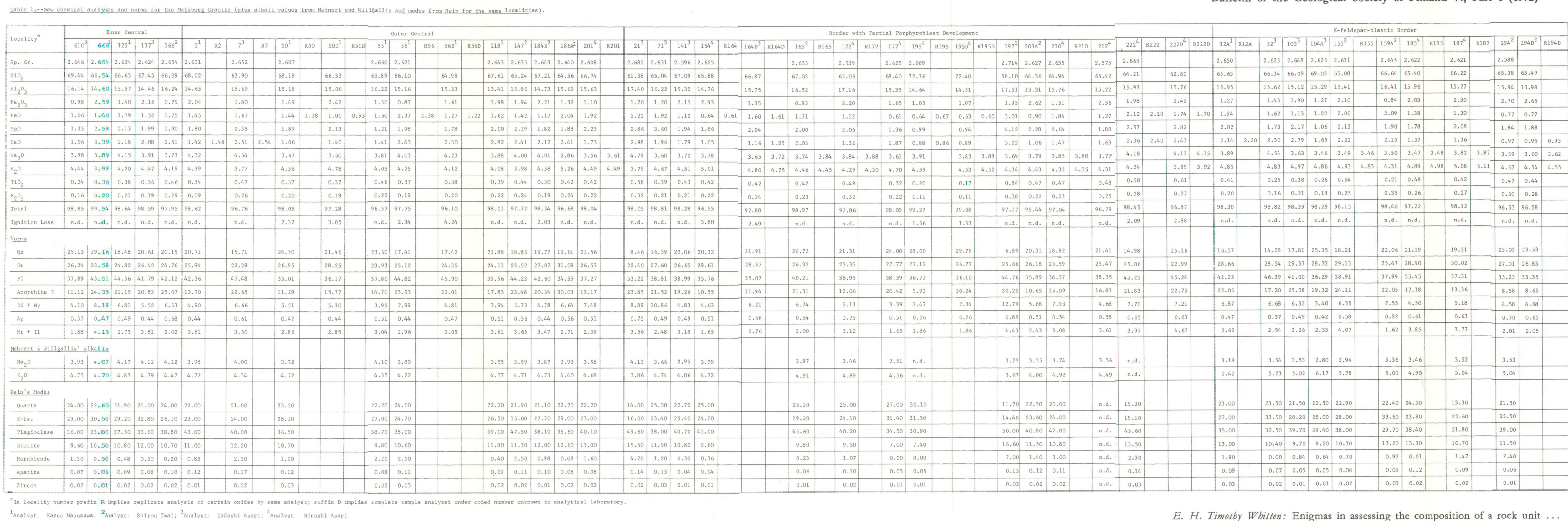

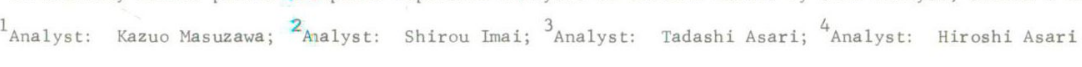

E. H. Timothy Whitten: Enigmas in assessing the composition of a rock unit 